Archived version from NCDOCKS Institutional Repository http://libres.uncg.edu/ir/asu/

\title{
Appalachïan
}

B O O N E, N O R T H C A R O L I N A

\section{State Of The Science Of Nursing Presence Revisited: Knowledge For Preserving Nursing Presence Capability}

\author{
By: Rebecca L. Turpin, RN, MSN, NEA-BC, PhD(c)
}

\begin{abstract}
Nursing presence has been a central focus for theorists, researchers, educators, and practicing professional nurses for over a half a century. Knowledge development and measurement of this experience is crucial at a time when human communication is becoming more impersonal, and nursing presence capability is potentially declining . A literature search was conducted using Cumulative Index to Nursing and Allied Health Literature and other discipline-specific databases . Extensive manual review of all relevant journals, reference lists, and additional publications were explored and synthesized. This article provides an updated state of the science report on nursing presence in regard to cross-discipline conceptual comparison, nursing theoretic model development, and instrument development .
\end{abstract}

Turpin, R. (2014). "State of the Science of Nursing Presence Revisited: Knowledge for Preserving Nursing Presence Capability." International Journal for Human Caring (INT J HUM CARING), 2014; 18(4): 14-29. (16p). Version of record avaiulable at: https://login.proxy006.nclive.org/login?url=http://search.ebscohost.com/

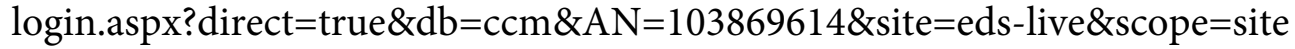




\title{
State of the Science of Nursing Presence Revisited: Knowledge for Preserving Nursing Presence Capability
}

\author{
Rebecca L. Turpin, RN, MSN, NEA-BC, PhD(c), East Tennessee State University, Tennessee Technological University
}

\begin{abstract}
Nursing presence has been a central focus for theorists, researchers, educators, and practicing professional nurses for over a half a century. Knowledge development and measurement of this experience is crucial at a time when human communication is becoming more impersonal, and nursing presence capability is potentially declining. A literature search was conducted using Cumulative Index to Nursing and Allied Health Literature and other discipline-specific databases. Extensive manual review of all relevant journals, reference lists, and additional publications were explored and synthesized. This article provides an updated state of the science report on nursing presence in regard to cross-discipline conceptual comparison, nursing theoretic model development, and instrument development.
\end{abstract}

Keywords: nursing presence, presencing, theory, model, framework, research, instrument

\section{Introduction}

Nursing presence capability is the competency of a nurse in enacting an interrelational experience with a patient that produces positive patient outcomes. This capability is often equated to an individual's ability to demonstrate art in nursing practice. Nursing presence occurs when both the nurse and patient are mutually open to one another, and the nurse spends himself or herself on behalf of the patient in such a way to meet patient needs. This behavioral concept has been explored and analyzed using several methods over half a century, yet even with this effort, nursing presence continues to retain a quality of sacredness and an internally experienced nature that many believe to be too internal to fully describe, understand, or enumerate. For many reasons, the concept of presence remains heavily bound to its origins of mysticism and existentialism, thus making measurement of the phenomenon elusive. $A$ review of the concept's origins helps identify reasons for this dilemma.

Nursing presence was probably first defined by Florence Nightingale as a rare healing presence as denoted by Dossey (2000). Smith (2001) chronologically outlined the nursing literature from the 1960s forward and provided a convincing rationale for the connections between nursing presence and spiritual presence in Judaism, Islamism, and Christianity. Writings of the existentialist philosophers Marcel, Heidegger, and Buber helped identify clear origins for nursing presence. Heidegger's (1962) Dasein (being there) described the concept as an intentional action of making oneself available to be with and understand another person. Marcel (1951) defined presence as capability of being with someone in need with the whole of himself. Marcel's writings also supported the belief that presence is mystical and metaphysical, and therefore cannot be objectified or explained, rather only felt (Smith, 2001). In the 1970 translation of Buber's "I and Thou" (Buber, 1970), full presence involved a relational encounter and relationships were described as exclusive and unique. These early writings provide insight to the origins of nursing presence and its elusive nature. Reflection on nursing professional history and traditions provides contextual support for its perceived mystical quality.

Hospitals historically served as the site for nurse training and care provision. Hospitals were often established by religious organizations, promoting the belief that healing was dependent on spiritual connection and intervention. Mandated white nursing attire symbolized purity of spirit, thus adding to the spiritual nature of caregiving. Even today, nurses are equated to angels. This symbolism and historic context have likely reinforced notions on the spiritual nature of the interpersonal connection between nurse and patient. Nursing practice seeks to promote healing and nursing presence equates to a healing presence. This background forms the basis for why defining nursing presence has generally been accepted as primarily qualitative and spiritual in nature, thus obscure to strict definition or measurement.

In spite of this long-held belief that nursing presence is elusive, early nurse theorists sought to define what made nursing unique as a professional discipline and distinct from the medical profession. Thus, the ability to connect with patients in a uniquely healing presence was considered a key concept of grand nursing theory and as a result, interpersonal relationships and nursing presence are a central focus in many early nursing theories (Benner, 1984; Ferlic, 1968; Leininger, 1991; Newman, 1986; Orlando, 1961; Parse, 1981; Paterson \& Zderad, 1976; Peplau, 1952; Rogers, 1970; Swanson, 1991; Travelbee, 1966; Vaillot, 1962, 1966; Watson, 1985).

Nursing presence is likely an underlying assumption in many other interpersonal models while not specifically identified by name. Additionally, several texts have been written that attempt to describe the phenomenon of presence further from different disciplinary standpoints in an effort to formalize its effect, usage, and importance in practice, and particularly in nursing (Koerner, 2007; Newman, 2008). The concept of presence is also identified in other non-nursing, professional interactions such as those found in education, psychiatry and counseling, and leadership, yet there is lack of understanding of how these disciplines' concept of presence compares with nursing's concept of presence. For this reason, it is important to clarify and compare the term presence across disciplines to better understand what may make it unique to the nursing profession. Clear and accurate knowledge regarding facilitation of presence unique to nursing is becoming increasingly more important for several reasons.

\section{Preserving Nursing Presence Capability}

Nursing presence is a behavioral concept that is considered essential in order for the nursepatient relationship to be effective and is tied to positive patient outcomes. The capability of nurses to create caring and effective moments and environments is currently of central concern in all healthcare settings, but its importance has dramatically increased in the acute care hospital setting. Rutherford (2012) made this concern very clear in her proposed nursing value structure model. Key antecedents and attributes of nursing presence such as nursing intuition, nursing trust, nursing care, and nursing knowledge are linked with positive patient outcomes, and these concepts together define the amount of health value profitability.

It is argued that nursing care is now the driver of healthcare profitability based on the ability to achieve outcomes in a cost-effective and efficient manner. Andrus (2013) also described its significance. A direct relationship between nursing's ability to create caring presence and the current metrics used by the Centers for Medicare and Medicaid Services (CMS) to evaluate patient satisfaction is explained. As part of the Affordable Care Act, patient satisfaction metrics, otherwise known as Hospital Consumer Assessment of Healthcare Providers and Systems (HCAHPS), are used by CMS to determine value-based purchasing reimbursements or penalties for hospitals based on patient perception (Department of Health and Human Services, 2012). Holistic nursing practice with enacting caring presence is suggested as the best practice for ensuring optimal financial viability within the hospital setting. Therefore, a hospital's potential economic survival may depend on the capability of nurses' collective 
abilities to routinely create nursing presence.

This comes at a time when many trends in generational and workforce factors are impeding or diminishing this capability.

Healthcare reimbursements are being decreased, and as a result hospitals are constrained from hiring experienced, more costly workers due to economic pressures. Less experienced and younger nurses just entering the workforce may be less capable at using nursing presence and yet more valued to fill positions with due to lower salary levels. Along with these challenges, the newest generation entering the nursing workforce has a markedly different communication style than prior generations, preferring to communicate via text, email, etc., versus face-to-face communication (Metcalf \& Putnam, 2013). Additionally, nursing care is currently being provided using ever increasing technology with use of electronic healthcare records, telehealth, and personal data assistants, all of which may erode the "in-person," interpersonal interchange that traditionally took place at the bedside. It is unknown whether these low-touch environments may decrease holistic care or provide access to care that would not have been available otherwise. These changes in the healthcare delivery system have resulting effects in the nursing education system.

To meet the increasing need for nursing personnel, nursing schools maintain a primary focus on content-driven education to ensure successful passing of National Council License Examination (NCLEX-RN®) to bolster the nursing workforce. A knowledge worker that can quickly and effectively assume patient care with the least orientation possible is the desired candidate for employment in hospital settings. The content-laden educational burden minimizes the provision of high quality education focused on communication skills and personal interrelationships with patients. Content and practice for expertise in interpersonal skills are at best minimally interwoven into courses throughout the curriculum. These skills may have become significantly deemphasized due to the overburdened focus on curricula that are content saturated (Giddens \& Brady, 2007). Nursing school admission and selection criteria are most often based on grade point average, nursing grade point average, pre-testing success, and success in science courses. There is limited research that supports use of interview or essay (to evaluate interpersonal skills) as selection criteria for predicting nursing school success (Schmidt \& MacWilliams, 2011).

Nursing is one of the most stable career paths in the current U.S. economy. As a result, applications to nursing school are increasing. Many applicants are not entering the discipline based on a higher calling to give of self. Typical personality and emotional traits that assisted nursing students to be successful in providing holistic care may be missing from the applicant pool. The skill set or personal characteristics necessary to become proficient in nursing presence is no longer a prerequisite for entry, and typically there is sole reliance on a high grade point average to make as selection criteria. The nursing educational system thus is becoming more and more the factory of knowledge workers.

\section{Problem Statement}

Nursing presence capability is at risk for decline. This capability that sets the nursing profession apart must be preserved. This problem is of significance importance in inpatient settings where $59 \%$ of U.S. nurses are employed (Feldstein, 2005), and where economic detractors, as previously discussed, will have the largest negative impact. It is essential that nurses fully understand how nursing presence capability can be optimized. Nursing presence must be unveiled and demystified. Nursing presence capability can only be fostered when there is a full understanding of: 1) what makes nurse presencing unique; 2) what the current state of knowledge regarding nursing presence in inpatient settings is; and 3) what reliable and valid instruments are available to determine patients' perception of nursing presence. Evaluating disciplinary boundaries, current research on nursing presence in hospitals, and measures of nursing presence may help safeguard a future in which care environments are proactively designed to meet interpersonal needs of patients while ensuring that the art of nursing not only is sustained, but flourishes through optimal education of new professional nurses.

\section{Aim}

The aim of this article is to explore the current state of the science on nursing presence with a focus to describe interdisciplinary boundaries, knowledge gleaned from inpatient research on nursing presence, and the status of nursing presence instrumentation (theoretic models or instruments) which may further guide future research and provide insight for nurse educators in teaching nursing presence capability. If the essence of nursing is to be preserved and not diminished, the components of nursing presence must be defined, refined, and measured. This knowledge will enable nursing faculty and other nursing leaders to ensure that the essence of effecting nursing presence can be taught and role modeled effectively. This knowledge may assist organizations in researching to evaluate their environments of care for best practices in designing healthcare settings for optimal delivery of this much needed interaction. As nurse presencing leads to improved patient outcomes and additional improved professional satisfaction for individual nurses, it is of vital importance to all healthcare settings. Through this type of synthesis, useful knowledge and instruments can be developed so that the nursing profession is optimally prepared to educate new nurses for care provision in futuristic nursing care environments.

The purpose of this study is to synthesize the literature on the phenomenon of nursing presence, as it relates to disciplinary boundaries, inpatient nursing presence research, and nursing presence metrics. To accomplish this, a systematic review of research, review literature, theoretical models, and instruments was conducted. This study aimed to answer three distinct research questions:

1. How does nursing presence compare to presence within other helping disciplines?

2. What knowledge has been discovered in nursing presence research as it relates to inpatients?

3. What nursing presence theoretical models and instruments exist that include measurable nurse characteristics inherent in the nurse-patient interaction? Which models have been tested and what is their reliability and validity of identified instruments? In order to evaluate the existing literature sequentially, a strategic method for systematic review was undertaken.

\section{Method}

This systematic review was conceptualized with the methodology provided by Cooper (1998) using five stages of research synthesis. The five stages are as follows: 1) problem formulation, 2) literature search, 3) data evaluation, 4) data analysis and interpretation, and 5) presentation of the results. Stage one includes problem formulation, development of the research question, identification of concepts and relationships, delimiting the review, and outline of a coding mechanism in advance. For purposes of coding, theoretical literature was evaluated using Kirkevold's (1997) 4-point coding. Theoretical literature with a score of 3 to 4 was included for review and analysis, but the literature had to include information value. For coding research literature, Whittemore's (2005) 11-point quality criteria were used, and research with scores of 7 to 11 were required for inclusion.

The literature search included a variety of databases including CINAHL, PsycINFO, ERIC, Business Source Complete, and Web of Science. The literature search was initially done in a broad manner using each database searching only for the concept of presence within the title. CINAHL was the most likely to render literature from nursing and allied health, therefore it was initiated first. Literature in all databases was 
limited to English language items. As prefixes within disciplines were discovered, further targeted searching was conducted within each database. For example, in CINAHL, the word presence had multiple meanings not reflective of only human connection, for example (presence of parents during resuscitation), therefore the search was limited to the search term of "nurse" or "nursing" or "caring" plus "presence" done under the category of all text to ensure that the focus of the literature was specific to the appropriate prefix. From this extensive review, documents that were pertinent to human relational use of the term presence were retrieved. Publication dates were limited from January 1988 to October 2013. In psychology and counseling, key prefixes included "therapist presence" or "therapeutic presence" to narrow the search within these fields, and then an additional search using these prefixes was conducted in PsycINFO. In like manner, the education literature was conducted in both CINAHL and ERIC databases using identified prefixes of "teaching" or "teacher" presence which was essential in narrowing down the educational literature. Finally, management literature was searched first for presence, and then narrowed down with the prefixes of "leader" or "leadership" to extract data from the management literature. As literature on presence within these prefix categories was extensively reviewed, all reference lists were evaluated for further pertinent literature and sources.

From this point, the nursing literature was categorized into one of three categories: 1) concept analyses/synthesis, 2) research, or 3) models/frameworks/instruments. In several cases, research articles may additionally have contained models or metrics of interest as well. To ensure that potential literature was not overlooked, additional search terms were used in CINAHL to identify "presence" plus "model," "theory," or "framework" and to identify "presence" plus "instrument," "scale," "questionnaire," or "tool."

\section{Results}

Presence literature resulting from other disciplines included sources from education, psychology/counseling, and management. Teaching or teacher presence was primarily found in literature and research involving online learning and 10 sources were included (Bangert, 2008; Fengfeng, 2010; Garrison, Cleveland-Inez, \& Fung, 2010; Kornelson, 2006; Meijer, Korthagen, \& Vasalos, 2009; Rodgers \& RaiderRoth, 2006; Sharda et al., 2004; Shea \& Bidjerano, 2009, 2010; Shea \& Vickers, 2010). The psychiatric/counseling search rendered 10 articles (Crane-Okada, 2012; Dunn, Callahan, Swift, \& Ivanovic, 2013; Fraelich, 1989; Geller, 2001; Geller \& Greenberg, 2002; Geller,
Greenberg, \& Watson, 2010; Granick, 2011, McCollum \& Gehart, 2010; Robbins, 1998; Tannen \& Daniels, 2010). Seven sources were included from management literature (Baldoni, 2010; Fairhurst, 2009; Halpern \& Lubar, 2004; Rosengren, Athlin, \& Segesten, 2007; Scouller, 2011; Senge, Scharmer, Jaworski \& Flower, 2004; Su \& Wilkins, 2013). The nursing literature was next explored.

Within nursing literature, the results were significantly larger. Non-research literature consisted of 15 review articles with a primary focus on nursing presence; seven primary concept analyses; several syntheses of nursing presence independently or comparatively between nursing presence and other concepts. Two nursing texts were identified specific to nursing presence (Koerner, 2007; Newman, 2008). In regard to nursing research studies, 32 studies were evaluated to determine their fit and were delimited to inpatient settings. The resultant subset included 22 sources included in the study. This review indicates a proliferation of nursing presence literature since Smith's (2001) analysis. In all, nine of 15 review articles, five of seven primary concept analyses, four of six syntheses/ comparable analyses, two books and 25 of 32 research studies have been completed post2001. This indicates only a moderate increase in available nursing-specific literature and data to analyze for content over a 12-year span.

\section{Data Analysis}

Consecutive integrative reviews were conducted to evaluate the three research questions. The literature was compared for congruent themes between disciplines, within nursing research findings and models. An iterative review process was undertaken over several months to compare the data related to each research question.

\section{Research Question 1}

To evaluate interdisciplinary boundaries of the concept presence, extracted data were compiled into categories and then subcategories, resulting in a few common themes across disciplines. Common themes were identified by reading all resultant literature, reflecting on content and making continual notes throughout the review procedure. Additionally, references cited within literature when appropriate were also read and evaluated for inclusion. Definitions of presence were identified within each discipline.

\section{Definitions of Presence}

Teaching presence is defined as "a state of alert awareness, receptivity, and connectedness to the mental, emotional, and physical workings of both the individual and the group in the context of their learning environments, and the ability to respond with a considered and compassionate best next step" (Rodgers \& Raider-Roth, 2006, p. 266). Therapeutic presence is defined as bringing one's whole self into the encounter with clients, by being completely in the moment on multiple levels: physically, emotionally, cognitively, and spiritually (Geller \& Greenberg, 2002). Leader presence was defined as "authenticity" and "projection of the individual that brings people to follow him or her for a common purpose" (Baldoni, 2010, p.2).

\section{Definition of Nursing Presence}

Nursing presence is not seen as mere physical attendance of the nurse's body beside the patient as the dictionary definition of presence could provide. Instead nurse presence has been generally understood as an actual "connection" within the nurse-patient relationship that is felt during interactions by both patient and nurse. This type of behavioral concept is of primary interest to nurse researchers (Morse, 2000) and best analyzed and/or appraised using a method that is congruent with its contextual nature. By contrast, several authors have analyzed the concept of nurse presence using other methods which are more congruent with positivist paradigms (Hessel, 2009; Hines, 1992; Tavernier, 2006) or just conducted concept analysis without a stated methodology or just as a literature review (Melnechenko, 2003; Zyblock, 2010). Significant analysis has been done with the concept of presence using metasyntheses either solely (Finfgeld-Connett, 2006; Minicucci, 1998), or to compare presence with other related concepts (Finfgeld-Connett, 2008a; FinfgeldConnett, 2008b; Fredriksson, 1999), or in collaboration with qualitative studies (Fuller, 1991). Although several definitions of nursing presence were identified, for the purposes of this research, nursing presence is defined as: ...an intersubjective encounter between a nurse and a patient (based on patient invitation) in which the nurse encounters the patient as a unique human being in a unique situation and chooses to spend him/ herself on the patient's behalf. (Doona, Haggert, \& Chase, 1997)

Definitions of presence among disciplines are quite different. Teaching presence has some similarities to nursing presence in that there is focus on the inward perception and connectedness, however, education's definition additionally focuses on the broader dimension of social presence which is absent from the nursing definition. Therapist presence is more closely aligned with the nursing definition in that the focus is on the sole inward interaction and is viewed based on levels. Leadership presence is outwardly focused on projection of image to achieve connections and followership, instead of the interpersonal connection itself. 
Although Morse (2004) advised that "clutter" in the literature by the proliferation of the same or similar concepts with different names inhibits deep concept development and use from a theoretical, research, or practice standpoint, nursing is a discipline that traditionally has borrowed theory and knowledge from other disciplines. McEwen (2007) supports this idea of conceptual knowledge in nursing originating from both nursing and other disciplines. While not the central focus of this analysis, failure to incorporate conceptual data from other disciplines may lead to lack of awareness of key conceptual linkages. Only one reference was located that demonstrated cross-discipline exploration on presence between psychology and nursing (Tannen \& Daniels, 2010). Therefore, there is further need to evaluate these similarities based on conceptual analysis categorization inclusive of pre-conditions, attributes, and post-conditions of the phenomenon. Findings of this integrative review indicated similarities exist between nursing presence and other disciplines' understanding and use of the term. Table 1 provides an overview of these similarities in terms of antecedents, attributes, and outcomes.

Themes identified with the integrative review indicate that presence is generally identified as "being with" another person resulting in positive

Table 1.

Antecedents, Attributes, and Outcomes of Presence by Disciplines

\section{Pre-conditions of Presence by Disciplines}

\section{Nursing}

Patient conditions (has a need, invites the relationship, openness, vulnerability)

Nurse conditions (willingness, personal and professional maturity, competence, in touch with self, willing to be involved, vulnerability) Environmental conditions (conducive work environment, time management, or quality management)

\section{Psychology, Sociology, Counseling}

Patient conditions (request for help, openness)

Therapist conditions (pre-session preparation, mindfulness of own reactions, bias)

Environmental conditions (privacy)

\section{Education}

Student conditions (openness, readiness, awareness of online systems) Teacher conditions (openness, ability for self-disclosure, vulnerability) Environmental conditions (trusting environment, knowledge of systems, systems that respond readily that create social presence among students)

\section{Management}

Employee conditions (pre-conceived perceptions, ability to identify with leader)

Leader conditions (pre-planning, rehearsal as in acting)

Environmental conditions (open, supportive to change)

\section{Attributes of Presence by Disciplines}

\section{Nursing}

Relationship features (trusting, intimacy, interpersonal reciprocity (working together), knowing the patient or nurse (being familiar)

Nurse features (expert nursing, demonstrating sensitivity, holism, and spirituality, ability to give of self, availability, listening \& hearing, advocacy (being for), facilitation, monitoring progress, responsiveness to patient cues, full attention/attentiveness, maintenance of psychological presence ability to adapt to unique situations, advocacy (being for), instills hope, monitoring progress, and teaching) Intentionality versus Instinctual Four behavioral levels: (physical, therapeutic, holistic, spiritual) Depth levels: (being there, partial presence, to full presence based on patient cues)

\section{Psychology, Sociology, Counseling}

Therapist features (openness to all client experience, openness to own experiences, ability to be with the client, capacity to respond, attention to the moment, authenticity, intentionality)

\section{Education}

Teacher design of education

Facilitation

Monitoring progress

Teaching

Interactivity

Assessment (ongoing)

Three levels: lurking, supporting, and leading

\section{Outcomes of Presence by Disciplines}

\section{Nursing}

For patient: decreased stress, isolation, distress, and vulnerability; improved coping, problem-solving, physical conditions, maternal bonding, self-esteem, adaptive behavior and ability to change, safety, mental and physical well-being; self-care; connectedness; and personal growth.

For nurse: improved mental well-being, professional satisfaction, calm environment

\section{Psychology, Sociology, Counseling}

For patient: improved mental status and ability to function in normal activities, improved decision-making and self-concept

\section{Management}

Leader features (reaching out, expressiveness, self-knowing, empathy, deep listening, authenticity, attentive in the moment, openness to self and others, narration)

\section{Education}

For student: improved cognitive presence (or recognition of gaining knowledge) and improved sense of social presence within the online learning environment

\section{Management}

Employee enthusiasm, improved human relations, collaboration \& positive work environment, establishment of trust between leader and employees 
outcomes, and/or helping, mentoring, or teaching focus in the relationships between nurse and patient(s), teacher and student(s), therapist and patient/client(s), or leader and employee(s). In teaching, presence in the social realm (student to student presence) as well as within the teacher realm (presence of teacher with student), or absence thereof, are key uses of the term. Teacher presence is a helping relationship akin to the nursing presence relationship. Teacher presence is extensively evaluated qualitatively and quantitatively for determination of its key attributes along with its significance as a key concept within the community of inquiry theory. Antecedents of teacher presence include selfdisclosure, connection, openness, vulnerability, inviting presence, and development of a trusting environment. Common attributes of teacher presence include facilitation, monitoring of progress, teaching, interactivity, and assessment. Outcomes of teacher presence include increases in social presence and cognitive presence as well as self-efficacy.

Psychology and counseling literature focus on therapeutic alliance more than therapeutic presence. Partnership attributes are more emphasized than the therapist's ability to enact presence. Antecedents to therapist or therapeutic presence include pre-session, preparation, and mindfulness as a strategy for teaching awareness prior to engaging in presence. Attributes of therapist presence include being available, openness to all client's experience, openness to own experience in being with the client, capacity to respond, attention to the moment, authenticity, and intention. The primary outcomes for therapeutic presence are improved mental or social functioning for the patient.

Management literature reveals minimal literature on concept development of presence and seems superficial by comparison to the other disciplines of nursing, education or psychology and counseling. Several books offer good theoretical background on leadership presence or its use, although most sources offer guidance on personal presence attainment (i.e., image) more than with expertise in relationship presence. Attributes of leadership presence include reaching out, expressiveness, selfknowing, being in the moment, empathy, listening, authenticity, deep listening, and openness. Outcomes of leader presence are described as enthusiasm, improved human relations, collaboration, and an improved work environment.

In the area of antecedents, several commonalities are noted. In nursing, antecedents of acceptance of self or being in touch with self compare to mindfulness in the counseling literature and self-knowing in the management literature. Likewise, self-disclosure in teaching antecedents would not be possible without self- knowing. Openness is common in either antecedents (nursing and teaching) or in attributes (counseling and management). Vulnerability is necessary for both nurse and patient, yet the literature shows the teacher alone needing to show vulnerability to his or her students to help facilitate a connection. Other primary common attributes of all disciplines mentioned are: 1) being attentive in the moment, 2) authenticity, 3) trusting relationships, 4) availability, and 5) interaction in terms of listening and monitoring of progress. Teaching is a key attribute in both nursing and education. Outcomes common to nursing and education include increased self-care/self-efficacy and increased cognitive presence/understanding. Outcomes common to nursing (for nurses) and to management include collaboration and improved work environments. The idea that presence is achieved in levels is common to nursing, teaching, and therapy. Within nursing, presence is described based on levels. Presence is described by: 1) intensity/depth: presence, partial presence, full presence, and transcending presence (Osterman \& Schwartz-Barcott, 1996), 2) bedside, clinical, and healing presence (Godkin, 2001), 3) therapeutic levels: physical, psychological, and therapeutic (spiritual) (McKivergin \& Daubenmire, 1994), and 4) modes of presence: physical, therapeutic, holistic, spiritual (Easter, 2000). Teaching presence contains three levels: lurking, supporting, or leading. Therapeutic presence is experienced in behavioral levels: physically, emotionally, cognitively, and spiritually. Thus there is congruence between disciplines in quantifying presence based on depth, linear progression, or behavioral categories to better understand the phenomenon. Although several cross-discipline similarities exist, in general, the concept of nursing presence is more fully developed than that of presence within other disciplines. This is also evident in the quantity and quality of nursing publications and research completed since the last state of the science report.

\section{Research Question 2}

The findings for inpatient nursing presence research are provided in Table 2. Over two-thirds of nursing presence research has been conducted using qualitative approaches, which is consistent with a behavioral concept in early development. Qualitative study designs include exploratory \& descriptive (Brown, 1986; DuisNittsche, 2002; Hanson, 2004; Jackson, 2004; Mohnkern, 1992; Osterman et al., 2010), grounded theory (Edvardsson, Sandman, \& Rasmussen, 2011; Hain, Logan, Cragg, \& Van den Berg, 2007), phenomenology (Cohen, Hausner, \& Johnson, 1994; Davis, 2005; Pettigrew, 1988), interpretive (Reis, Rempel, Scott, Brady-Fryer, \& Aerde, 2010), and hermeneutics (Cantrell \& Matula, 2009; Doona, Chase, \& Haggerty, 1999; MacKimmon, McIntyre, \& Quance, 2005; Turner \& Stokes, 2006). The remaining six studies utilized quantitative methods: comparative (Busch et al., 2012; Papastavrou et al., 2011) and instrument development (Foust, 1998; Hansbrough, 2011; Hines, 1991; Kostovich, 2011). Based on this trajectory of studies, it can be concluded that quantitative research on nursing presence is in its infancy with only limited instrumentation. Review of instrumentation research will be discussed in a separate section. Key results from all research studies are outlined in Table 2 , but are summarized as follows.

Most notably, nursing presence and reassuring presence are supported as critical elements in defining the most important quality in the hospitalized patients' experience of care (Brown, 1986, Davis, 2005). In addition, the depth in mode of delivery of staff presence even with demented patients influenced patient wellbeing (Edvardsson et al., 2011). This finding supports the assertions of Rutherford (2012) and Andrus (2013) regarding the importance patients place on nursing relational care. Several studies provide more qualification related to attributes of nursing presence from a patient perspective (Cantrell \& Matula, 2009; MacKinnon et al., 2005), a nurse perspective (Doona et al., 1999; Hain et al., 2007; Hanson, 2004; Jackson, 2004; Mohnkern, 1992; Turner \& Stokes, 2006), or both (Cohen et al., 1994; Duis-Nittsche, 2002;

Osterman et al., 2010). Two studies evaluated family member perspectives on nursing presence (Pettigrew, 1988; Reis et al., 2010). Some findings support intentionality of nursing presence (Hain et al., 2007; Pettigrew, 1988; Reis et al., 2010) while another supports the intuitive nature of nursing presence (Osterman et al., 2010). Although small, one study (Busch et al., 2012), found no statistically significant differences between burn patients' pain medication usage when provided therapeutic touch versus nursing presence without touch, which is opposite of traditional thought that touch was an important feature during presencing. Interestingly, one large European study (Papastavrou et al., 2011) with surgical inpatients ( $n=1537)$, identified a significant difference between patient and nurse views on assurance of human presence, with nurses $(n=1148)$ rating their performance of nursing presence higher than that perceived by patients $(p<0.001)$. This clearly indicates a gap in what nurses believe they provide versus what patients expect to be provided. While this study may not be generalized necessarily to the United States as there are international differences in how hospital settings are designed, it is a large enough study to be considered crucial findings that need to be explored through future replicated research. In 
Table 2.

Nursing Presence Inpatient Research

\begin{tabular}{|c|c|c|c|c|c|c|c|}
\hline Author/Title & Study Design & $\begin{array}{l}\text { Sample Type } \\
\& \text { Size }\end{array}$ & $\begin{array}{l}\text { Data } \\
\text { Sources }\end{array}$ & Setting & $\begin{array}{l}\text { Research } \\
\text { Questions/ } \\
\text { Hypothesis }\end{array}$ & Instruments & Results/Comments \\
\hline Brown (1986) & $\begin{array}{l}\text { Qualitative, } \\
\text { descriptive }\end{array}$ & $\begin{array}{l}\text { Convenience, adult } \\
\text { hospitalized patients } \\
(n=50)\end{array}$ & $\begin{array}{l}\text { Taped \& transcribed } \\
\text { accounts of caring } \\
\text { nurse experiences }\end{array}$ & $\begin{array}{l}\text { Medical-surgical } \\
\text { area of hospital, } \\
\text { Northeast US }\end{array}$ & $\begin{array}{l}\text { To describe the } \\
\text { patient's experience } \\
\text { of caring by a nurse }\end{array}$ & NONE & $\begin{array}{l}\text { Reassuring presence by the } \\
\text { nurse was most important } \\
\text { quality in the experience of } \\
\text { "care." }\end{array}$ \\
\hline $\begin{array}{l}\text { Busch et al. } \\
\text { (2012) }\end{array}$ & $\begin{array}{l}\text { Quantitative, } \\
\text { comparative } \\
\text { two group }\end{array}$ & $\begin{array}{l}\text { Randomized block, } \\
\text { hospitalized patients } \\
\text { receiving either } \\
\text { therapeutic touch } \\
(\mathrm{TT})(n=8) \text { or nurse } \\
\text { presence (NP) } \\
(n=11)\end{array}$ & $\begin{array}{l}\text { Instruments, saliva } \\
\text { cortisol, pain } \\
\text { medication } \\
\text { administra-tion } \\
\text { records }\end{array}$ & $\begin{array}{l}\text { 20-bed burn ward in } \\
\text { Rotterdam, } \\
\text { Netherlands }\end{array}$ & $\begin{array}{l}\text { Will TT or NP have } \\
\text { different effects of } \\
\text { reducing anxiety, } \\
\text { pain, cortisol level, } \\
\text { and pain medication } \\
\text { in burn patients? }\end{array}$ & $\begin{array}{l}\text { Burn Specific Pain } \\
\text { Anxiety Scale } \\
\text { (BSPAS) for pre- } \\
\text { procedure pain/ } \\
\text { anxiety,\& Visual } \\
\text { Analog Thermoment } \\
\text { (VAT) for actual pain }\end{array}$ & $\begin{array}{l}\text { Anxiety: no statistically } \\
\text { significant differences found } \\
\text { between interventions except } \\
\text { by day } 10 \text { with post-procedure } \\
\text { anxiety } 19.0 \text { (TT) vs. } 38.7 \\
\text { (NP), } p \leq 0.05) \text {. Pain: no } \\
\text { statistically significant } \\
\text { differences between groups. } \\
\text { Cortisol: On day } 2 \text { of tx, the TT } \\
\text { group showed a statistically } \\
\text { higher cortisol level compared } \\
\text { with the NP group before } \\
\text { dressing change (12.2 vs. } 5.8 \text {, } \\
p=0.014) \text {. Pain medication: } \\
\text { NP patients received more } \\
\text { morphine than TT patients } \\
\text { on day } 1 \text { ( } p=0.037) \& \text { day } \\
2(p=0.015) \text {. When taking } \\
\text { all pain medications together } \\
\text { in a sum score, no significant } \\
\text { differences were noted } \\
\text { between groups. }\end{array}$ \\
\hline $\begin{array}{l}\text { Cantrell \& } \\
\text { Matula (2009) }\end{array}$ & Hermeneutic & $\begin{array}{l}\text { Purposive, } \\
\text { childhood cancer } \\
\text { survivors, }(n=11) \\
3 \text { male, } 8 \text { female }\end{array}$ & $\begin{array}{l}\text { Focus group \& } \\
\text { individual interviews }\end{array}$ & $\begin{array}{l}\text { Oncology center in } \\
\text { North East US }\end{array}$ & $\begin{array}{l}\text { Describe } \\
\text { experiences in being } \\
\text { cared for by } \\
\text { pediatric oncology } \\
\text { nurses }\end{array}$ & NONE & $\begin{array}{l}\text { Participants knew when } \\
\text { nurses were authentic and } \\
\text { made effort to be present } \\
\text { emotionally for them. Expert } \\
\text { care seen as incomplete } \\
\text { without compassion. }\end{array}$ \\
\hline $\begin{array}{l}\text { Cohen et al. } \\
\text { (1994) }\end{array}$ & $\begin{array}{l}\text { Phenomen- } \\
\text { ological }\end{array}$ & $\begin{array}{l}\text { Convenience, } \\
\text { nurses on a surgical } \\
\text { unit }(n=24) \text { who } \\
\text { identified adult } \\
\text { surgical patients, } \\
\text { interviewed post- } \\
\text { discharge at home } \\
(n=24)\end{array}$ & $\begin{array}{l}\text { Open-ended } \\
\text { interviews }\end{array}$ & $\begin{array}{l}\text { Surgical unit } \\
\text { US }\end{array}$ & $\begin{array}{l}\text { Describe patient } \\
\text { experiences as } \\
\text { compared to nurse } \\
\text { accounts }\end{array}$ & NONE & $\begin{array}{l}\text { Attentive presence is } \\
\text { described by patients when an } \\
\text { attentive attitude is coupled } \\
\text { with understanding and } \\
\text { helpfulness/responsiveness. }\end{array}$ \\
\hline Davis (2005) & $\begin{array}{l}\text { Phenomen- } \\
\text { ological }\end{array}$ & $\begin{array}{l}\text { Purposive, \& } \\
\text { conceptually driven } \\
\text { sequential, adult } \\
\text { patients }(n=11) \\
7 \text { female, } 4 \text { male }\end{array}$ & Interview & South central US & $\begin{array}{l}\text { How do patients } \\
\text { describe good } \\
\text { nursing care? }\end{array}$ & NONE & $\begin{array}{l}\text { Nursing presence seen as } \\
\text { defining characteristic of good } \\
\text { nursing care: most common } \\
\text { theme was nursing presence } \\
\text { (being there \& being with). In } \\
\text { descriptions of bad nursing } \\
\text { care, presence was } \\
\text { conspicuously absent. }\end{array}$ \\
\hline $\begin{array}{l}\text { Doona et al. } \\
\text { (1999) }\end{array}$ & Hermeneutic & $\begin{array}{l}30 \text { nursing j } \\
\text { udgment narratives } \\
\text { from } 3 \text { previous } \\
\text { studies }\end{array}$ & $\begin{array}{l}\text { Transcripts from } \\
\text { each data set } \\
\text { ( } n=10 \text { per set) }\end{array}$ & $\begin{array}{l}\text { Critical care, } \\
\text { perinatal \& } \\
\text { psychiatric care } \\
\text { settings, Northeast } \\
\text { US }\end{array}$ & $\begin{array}{l}\text { 1. What are the } \\
\text { common features of } \\
\text { the context of } \\
\text { nursing judgment? } \\
\text { 2. What are the } \\
\text { features of the } \\
\text { nurses' connection } \\
\text { with the patient that } \\
\text { contribute to nursing } \\
\text { judgment? }\end{array}$ & NONE & $\begin{array}{l}\text { Six features of nursing } \\
\text { presence were identified: } \\
\text { uniqueness, connecting with } \\
\text { the patient's experience, } \\
\text { sensing, going beyond the } \\
\text { scientific date, knowing (what } \\
\text { will work \& when to act), and } \\
\text { being with the patient. }\end{array}$ \\
\hline
\end{tabular}


Table 2. (continued)

\begin{tabular}{|c|c|c|c|c|c|c|c|}
\hline Author/Title & Study Design & $\begin{array}{l}\text { Sample Type } \\
\& \text { Size }\end{array}$ & $\begin{array}{l}\text { Data } \\
\text { Sources }\end{array}$ & Setting & $\begin{array}{l}\text { Research } \\
\text { Questions/ } \\
\text { Hypothesis }\end{array}$ & Instruments & Results/Comments \\
\hline $\begin{array}{l}\text { Duis-Nittsche } \\
\text { (2002) }\end{array}$ & $\begin{array}{l}\text { Qualitative, } \\
\text { descriptive }\end{array}$ & $\begin{array}{l}\text { Seven nurse-patient } \\
\text { dyads }\end{array}$ & $\begin{array}{l}\text { Semistructured } \\
\text { interviews }\end{array}$ & South central US & $\begin{array}{l}\text { Describe the nature, } \\
\text { experience and } \\
\text { impact of nursing } \\
\text { presence within the } \\
\text { nurse/patient } \\
\text { relationship }\end{array}$ & $\begin{array}{l}\text { Nurse \& Researcher } \\
\text { developed interview } \\
\text { tool }\end{array}$ & $\begin{array}{l}\text { Nurse themes of nursing } \\
\text { presence: knowing the patient, } \\
\text { responding to needs, attitudes/ } \\
\text { beliefs, bonding with the } \\
\text { patient, influencing others, \& } \\
\text { relationships. Patient themes: } \\
\text { knowing me, accessibility, } \\
\text { bonding, supporting \& } \\
\text { encouraging me/others, } \\
\text { healing. }\end{array}$ \\
\hline $\begin{array}{l}\text { Edvardsson } \\
\text { et al. (2011) }\end{array}$ & $\begin{array}{l}\text { Grounded } \\
\text { theory }\end{array}$ & $\begin{array}{l}\text { Patients with } \\
\text { moderate to severe } \\
\text { dementia }\end{array}$ & $\begin{array}{l}\text { Participant } \\
\text { observation ( } 36 \\
\text { hours) }\end{array}$ & $\begin{array}{l}\text { 24-bed, psycho- } \\
\text { geriatric ward in } \\
\text { university hospital in } \\
\text { Sweden }\end{array}$ & $\begin{array}{l}\text { Explore the } \\
\text { psychosocial climate } \\
\text { and its influence on } \\
\text { the well-being of } \\
\text { people with } \\
\text { dementia in a } \\
\text { hospital psycho- } \\
\text { geriatric unit }\end{array}$ & NONE & $\begin{array}{l}\text { Different modes of staff } \\
\text { presence or absence } \\
\text { influenced patient well-being. } \\
\text { Modes: sharing place \& } \\
\text { moment (presence), sharing } \\
\text { place but not moment (task } \\
\text { orientation), sharing neither } \\
\text { place nor moment (absence). } \\
\text { Sharing place \& moment } \\
\text { associated with less } \\
\text { observations of anxious } \\
\text { behavior and more signs of } \\
\text { well-being (smiles, laughter) }\end{array}$ \\
\hline Foust (1998) & Quantitative & $\begin{array}{l}\text { Random, registered } \\
\text { nurses }(n=210)\end{array}$ & Survey instruments & South central US & $\begin{array}{l}\text { Examine } \\
\text { relationship of } \\
\text { presence, self- } \\
\text { esteem, and } \\
\text { demographic } \\
\text { characteristics of } \\
\text { registered nurses } \\
\text { and conduct } \\
\text { instrument } \\
\text { development }\end{array}$ & $\begin{array}{l}\text { Measurement of } \\
\text { Presence Scale } \\
\text { (Hines, 1991), MOP } \\
\text { Visual Analog Scale } \\
\text { (MOPVAS), \& } \\
\text { Rosenberg Self- } \\
\text { Esteem Scale } \\
\text { (RSES) }\end{array}$ & $\begin{array}{l}\text { Presence level and self- } \\
\text { esteem level was high with } \\
\text { respective means of } 231 \text {, } \\
S D=16.52 \text { and } 34, S D=4.46 \text {. } \\
\text { The mean of the MOPVAS } \\
\text { was } 85, S D=1.73 \text {. Reliability } \\
\text { MOPS = alpha of } .9106 \text {, for } \\
\text { Rosenburg's Self-Esteem } \\
\text { Scale alpha = 0.8571. Internal } \\
\text { consistency for MOPS } 0.8512 \text {. } \\
\text { Validity supported with low } \\
\text { correlations of MOPS and } \\
\text { MOPVAS } r=0.263 \text { ( } p=0.01 \text { ) } \\
\text { and MOPVAS and RSES } \\
r=.329 . \text { ( } p=.01 \text { ). MOPS } \\
\text { factor analysis subscale } \\
\text { factors was different than for } \\
\text { Hines, 1991, but similar. } \\
\text { Results supportive of } \\
\text { instrument measurement of } \\
\text { presence. }\end{array}$ \\
\hline $\begin{array}{l}\text { Hain et al. } \\
(2007)\end{array}$ & $\begin{array}{l}\text { Qualitative, } \\
\text { grounded } \\
\text { theory }\end{array}$ & $\begin{array}{l}\text { Convenience, expert } \\
\text { nurse participants } \\
(n=9)\end{array}$ & Interviews & $\begin{array}{l}\text { Ottawa, Ontario, } \\
\text { Canada }\end{array}$ & $\begin{array}{l}\text { Examine how critical } \\
\text { care nurses practice } \\
\text { nurse presence with } \\
\text { their patients }\end{array}$ & NONE & $\begin{array}{l}\text { Presence as a practice } \\
\text { emerged as a three-phased } \\
\text { process: 1) commitment, } \\
\text { (initial sensing \& engagement), } \\
\text { 2) presencing strategies, \& } \\
\text { 3) connection. Ways of being: } \\
\text { empathetic, authentic. Ways of } \\
\text { doing: advocacy, reassurance, } \\
\text { support. }\end{array}$ \\
\hline $\begin{array}{l}\text { Hansbrough } \\
\text { (2011) }\end{array}$ & $\begin{array}{l}\text { Quantitative, } \\
\text { instrument } \\
\text { development }\end{array}$ & $\begin{array}{l}\text { Convenience, } \\
\text { hospitalized patients } \\
(n=75), \& \text { nurses } \\
(n=24)\end{array}$ & Survey instruments & Western US & $\begin{array}{l}\text { What is the reliability } \\
\& \text { validity of the } \\
\text { PONS as tested } \\
\text { against a single-item } \\
\text { measure of patient } \\
\text { satisfaction? What is } \\
\text { the relationship } \\
\text { between PONS } \\
\text { score and levels of } \\
\text { nursing expertise } \\
\text { (NEL)? }\end{array}$ & $\begin{array}{l}\text { Presence of Nursing } \\
\text { Scale (PONS), } \\
\text { a single-item } \\
\text { measure of patient } \\
\text { satisfaction, \& Nurse } \\
\text { Expertise Level } \\
\text { (NEL) }\end{array}$ & $\begin{array}{l}\text { PONS reliable with Cronbach's } \\
\text { alpha }=0.937 \text {, Correlation } \\
\text { between PONS \& patient } \\
\text { satisfaction large as } \\
\text { determined by Spearmen's rho } \\
(p<0.01) \text {. Nursing expertise } \\
\text { level categorized for all nurse } \\
\text { participants. Correlations } \\
\text { between NEL \& PONS were } \\
\text { inconclusive. }\end{array}$ \\
\hline
\end{tabular}


Table 2. (continued)

\begin{tabular}{|c|c|c|c|c|c|c|c|}
\hline Author/Title & Study Design & $\begin{array}{l}\text { Sample Type } \\
\& \text { Size }\end{array}$ & $\begin{array}{l}\text { Data } \\
\text { Sources }\end{array}$ & Setting & $\begin{array}{l}\text { Research } \\
\text { Questions/ } \\
\text { Hypothesis }\end{array}$ & Instruments & Results/Comments \\
\hline $\begin{array}{l}\text { Hanson } \\
(2004)\end{array}$ & $\begin{array}{l}\text { Qualitative, } \\
\text { descriptive }\end{array}$ & $\begin{array}{l}\text { Random, } \\
\text { regionalized mailing } \\
\text { to critical care } \\
\text { nurses }(n=84)\end{array}$ & Mailed survey & Southwest US & $\begin{array}{l}\text { Identify categories } \\
\text { or patterns related } \\
\text { to caring based } \\
\text { on personal } \\
\text { experiences of } \\
\text { critical care nurses } \\
\& \text { determine } \\
\text { whether findings } \\
\text { validate Swanson's } \\
\text { caring theory }\end{array}$ & $\begin{array}{l}\text { Survey with } 13 \\
\text { demographic items } \\
\& 2 \text { open-ended } \\
\text { questions }\end{array}$ & $\begin{array}{l}\text { Being there included themes } \\
\text { of taking time to listen, asking } \\
\text { questions and allowing time to } \\
\text { talk, and doing little things. } \\
\text { This theme seemed to validate } \\
\text { Swanson's "Being With" } \\
\text { component of theory. }\end{array}$ \\
\hline Hines (1991) & $\begin{array}{l}\text { Quantitative, } \\
\text { exploratory }\end{array}$ & $\begin{array}{l}\text { Convenience, } \\
\text { registered nurses } \\
(n=324)\end{array}$ & Survey instrument & $\begin{array}{l}\text { Hospitals, clinics \& } \\
\text { locations for nurses } \\
\text { meeting in the } \\
\text { Midwest, West, } \\
\text { \& South US }\end{array}$ & $\begin{array}{l}\text { To test and explore } \\
\text { the Measurement of } \\
\text { Presence Scale } \\
\text { (MOPS) to conduct } \\
\text { scholarly inquiry } \\
\text { about the } \\
\text { phenomenon of } \\
\text { presence. Reliability } \\
\text { will be }>.70 \text { for the } \\
\text { tool and }>.60 \text { for } \\
\text { subscales }\end{array}$ & $\begin{array}{l}\text { Measurement of } \\
\text { Presence Scale } \\
\text { (MOPS) }\end{array}$ & $\begin{array}{l}\text { MOPS reliability with } \\
\text { Cronbach's alpha = } 0.9324 . \\
\text { Subscale alpha correlation } \\
\text { coefficients }>.060 \text {. Nine } \\
\text { subscales were interpreted: } \\
\text { 1) valuing/attending to self/ } \\
\text { others, 2) connecting, } \\
\text { 3) transacting, 4) enduring } \\
\text { memory from past, } \\
\text { 5) engaging for growth, } \\
\text { 6) encountering, 7) availability, } \\
\text { 8) person or even sustaining } \\
\text { memory, and 9) disclosing \& } \\
\text { enclosing. Correlation between } \\
\text { total MOPS and subscales } \\
\text { was significant at the } \\
0.01 \text { level. }\end{array}$ \\
\hline $\begin{array}{l}\text { Jackson } \\
\text { (2004) }\end{array}$ & Qualitative & $\begin{array}{l}\text { Homogenous, } \\
\text { criterion \& network, } \\
\text { medical-surgical } \\
\text { nurses }(n=11)\end{array}$ & $\begin{array}{l}\text { Semistructured } \\
\text { depth interviews }\end{array}$ & $\begin{array}{l}\text { University-affiliated, } \\
\text { community hospitals } \\
\text { in large metropolitan } \\
\text { area (US) }\end{array}$ & $\begin{array}{l}\text { What factors } \\
\text { contribute to nurses' } \\
\text { self-image as a } \\
\text { healer or self-image } \\
\text { of not being a } \\
\text { healer? }\end{array}$ & NONE & $\begin{array}{l}\text { Emergent themes: Healing is } \\
\text { about caring connections/ } \\
\text { relationships, \& involves } \\
\text { nursing presence (listening, } \\
\text { being with). }\end{array}$ \\
\hline $\begin{array}{l}\text { Kostovich } \\
\text { (2011) }\end{array}$ & $\begin{array}{l}\text { Quantitative, } \\
\text { field testing of } \\
\text { instrument }\end{array}$ & $\begin{array}{l}\text { Convenience, } \\
\text { acutely ill, } \\
\text { hospitalized adult } \\
\text { patients }\end{array}$ & Instrument & $\begin{array}{l}\text { Medical-surgical } \\
\text { units of hospital } \\
\text { Midwest, US }\end{array}$ & $\begin{array}{l}\text { Develop and } \\
\text { conduct } \\
\text { psychometric testing } \\
\text { on first patient- } \\
\text { perceived } \\
\text { measurement scale } \\
\text { for nursing presence }\end{array}$ & $\begin{array}{l}\text { Presence of Nursing } \\
\text { Scale, new } \\
\text { instrument }\end{array}$ & $\begin{array}{l}\text { Instrument addressed } 25 \text { items } \\
\text { identified by prior nursing } \\
\text { presence concept analysis and } \\
\text { based on Paterson \& Zderad's } \\
\text { (1976) theoretical framework. } \\
\text { Construct validity was } \\
\text { established by comparing } \\
\text { the total instrument score } \\
\text { with a single-item measure of } \\
\text { patient satisfaction with a very } \\
\text { high positive correlation (rpb = } \\
.801 \text { ). Reliability (Cronbach's } \\
\text { alpha) was } 0.95 \text { and test-retest } \\
\text { reliability of } 0.729 \text {. }\end{array}$ \\
\hline $\begin{array}{l}\text { MacKinnon } \\
\text { et al. (2005) }\end{array}$ & Hermeneutic & $\begin{array}{l}\text { Purposive, post- } \\
\text { partum women } \\
\text { within } 6 \text { months of } \\
\text { delivery }(n=6)\end{array}$ & $\begin{array}{l}\text { Audiotaped \& } \\
\text { transcribed } \\
\text { interviews }\end{array}$ & $\begin{array}{l}\text { Urban center in } \\
\text { Canada }\end{array}$ & $\begin{array}{l}\text { What meanings do } \\
\text { women in labor } \\
\text { attribute to the } \\
\text { intrapartum nurse's } \\
\text { presence during } \\
\text { their childbirth } \\
\text { experience? }\end{array}$ & NONE & $\begin{array}{l}\text { Nurse presence was the way } \\
\text { in which a nurse was "there for } \\
\text { them" described as: to be } \\
\text { available, be emotionally } \\
\text { involved, help create special } \\
\text { moments, hear/respond to } \\
\text { concerns, share responsibility } \\
\text { for keeping them safe, \& to be } \\
\text { a go between with them \& } \\
\text { family. Other key concepts } \\
\text { included nurse competence, } \\
\text { being known \& understood \& } \\
\text { getting to know the nurses. } \\
\text { Nursing presence involved } \\
\text { being there (physical } \\
\text { presence), being with } \\
\text { (emotional presence) \& being } \\
\text { for (advocacy). }\end{array}$ \\
\hline
\end{tabular}


Table 2. (continued)

\begin{tabular}{|c|c|c|c|c|c|c|c|}
\hline Author/Title & Study Design & $\begin{array}{l}\text { Sample Type } \\
\& \text { Size }\end{array}$ & $\begin{array}{l}\text { Data } \\
\text { Sources }\end{array}$ & Setting & $\begin{array}{l}\text { Research } \\
\text { Questions/ } \\
\text { Hypothesis }\end{array}$ & Instruments & Results/Comments \\
\hline $\begin{array}{l}\text { Mohnkern, S. } \\
\text { (1992) }\end{array}$ & Qualitative & Nurses $(n=15)$ & Interviews & Southwest US & $\begin{array}{l}\text { Describe } \\
\text { antecedents, } \\
\text { defining attributes \& } \\
\text { consequences of } \\
\text { presence }\end{array}$ & NONE & $\begin{array}{l}\text { Antecedents: Patient in need } \\
\text { who trusts the nurse, Nurse } \\
\text { with mission \& desire to help } \\
\text { patient (altruism), has an } \\
\text { affinity for patient, } \\
\text { demonstrates instinct, insight, } \\
\text { intuition, maturity/self- } \\
\text { confidence. Defining attributes: } \\
\text { initial physical closeness, } \\
\text { metaphysical connection/ } \\
\text { exchange. Consequences: } \\
\text { positive patient progress, } \\
\text { improved patient functioning or } \\
\text { death, patient desire for more } \\
\text { nurse contact, nurse } \\
\text { availability continues, nurse } \\
\text { personal \& professional } \\
\text { development promoted. }\end{array}$ \\
\hline $\begin{array}{l}\text { Osterman } \\
\text { et al. (2010) }\end{array}$ & $\begin{array}{l}\text { Qualitative, } \\
\text { descriptive }\end{array}$ & $\begin{array}{l}\text { Convenience, } \\
\text { nurses }(n=5), \\
\text { hospital inpatients } \\
(n=10)\end{array}$ & $\begin{array}{l}\text { Participant- } \\
\text { observation, with } \\
\text { informal \& formal } \\
\text { interviews }\end{array}$ & $\begin{array}{l}\text { 30-35 bed oncology } \\
\text { unit in a } 275 \text {-bed } \\
\text { community hospital } \\
\text { in New England, US }\end{array}$ & $\begin{array}{l}\text { Identify \& describe } \\
\text { various forms of } \\
\text { presence that } \\
\text { occurred with any } \\
\text { one nurse while } \\
\text { providing daily care } \\
\text { on an oncology unit. } \\
\text { Determine if } \\
\text { similarities existed in } \\
\text { the use of presence } \\
\text { between nurses }\end{array}$ & NONE & $\begin{array}{l}\text { Nursing presence was not a } \\
\text { deliberate nursing strategy. } \\
\text { Presence was embedded in } \\
\text { individual nurses' manner \& } \\
\text { approach \& easily identified by } \\
\text { patients. Cues from the } \\
\text { patients were the stimulus for } \\
\text { guiding the level of presence } \\
\text { provided by the nurse (partial } \\
\text { or full). Openness \& } \\
\text { spontaneity to respond \& alter } \\
\text { levels of presence was based } \\
\text { on the interplay between the } \\
\text { patient's needs and behaviors, } \\
\text { the current context of the unit } \\
\text { \& the nurse's past experience. }\end{array}$ \\
\hline $\begin{array}{l}\text { Papastavrou } \\
\text { et al. (2011) }\end{array}$ & $\begin{array}{l}\text { Quantitative, } \\
\text { descriptive } \\
\text { comparative }\end{array}$ & $\begin{array}{l}\text { Convenience } \\
\text { sample from } 34 \\
\text { hospitals. Surgical } \\
\text { inpatients ( } n=1537 \text { ) } \\
\text { \& their nurses for } \\
\text { that shift }(n=1148 \text { ) }\end{array}$ & $\begin{array}{l}\text { Participant- } \\
\text { completed } \\
\text { questionnaires }\end{array}$ & $\begin{array}{l}\text { Inpatient surgical } \\
\text { wards in six } \\
\text { European countries: } \\
\text { Cyprus, the Czech } \\
\text { Republic, Finland, } \\
\text { Greece, Hungary, \& } \\
\text { Italy }\end{array}$ & $\begin{array}{l}\text { Compare patients' \& } \\
\text { nurses' perceptions } \\
\text { of caring behaviors }\end{array}$ & $\begin{array}{l}\text { Caring-Behaviors } \\
\text { Inventory - } 24\end{array}$ & $\begin{array}{l}\text { Significant differences found } \\
\text { between patient and nurse } \\
\text { views on the sub-scale of } \\
\text { assurance of human presence } \\
\text { with nurses rating themselves } \\
\text { higher than the patients } \\
(p<0.001) \text {, while the sub- } \\
\text { scale of positive connectedness } \\
\text { was not significantly different. } \\
\text { Factors for assurance of } \\
\text { presence included: visiting the } \\
\text { patient, communicating, } \\
\text { encouraging calling, \& } \\
\text { responding to patient calls. }\end{array}$ \\
\hline $\begin{array}{l}\text { Pettigrew } \\
(1988)\end{array}$ & $\begin{array}{l}\text { Phenomen- } \\
\text { ological }\end{array}$ & $\begin{array}{l}\text { Purposive, family } \\
\text { members of cancer } \\
\text { patients }(n=6)\end{array}$ & $\begin{array}{l}\text { Unstructured } \\
\text { interviews }\end{array}$ & $\begin{array}{l}\text { After death of } \\
\text { terminal patient, } \\
\text { Western US }\end{array}$ & $\begin{array}{l}\text { What are the } \\
\text { essential elements } \\
\text { of the lived- } \\
\text { experience of the } \\
\text { nurse's presence } \\
\text { as experienced by } \\
\text { family members } \\
\text { or friends of a } \\
\text { terminally-ill cancer } \\
\text { patient? }\end{array}$ & NONE & $\begin{array}{l}\text { Nurse's presence evolved } \\
\text { around time of crisis. Presence } \\
\text { recognized by: deliberate } \\
\text { behavior, verbal affirmation, } \\
\text { good listening \& non-verbal } \\
\text { skills, clinical competency, } \\
\text { spiritual care, action beyond } \\
\text { ordinary, unrestricted } \\
\text { availability, compassion, } \\
\text { valuing personhood \& staying } \\
\text { power, nurse vulnerabilityl } \\
\text { investment. Occurs upon } \\
\text { invitation from the suffering. }\end{array}$ \\
\hline
\end{tabular}


Table 2. (continued)

\begin{tabular}{|c|c|c|c|c|c|c|c|}
\hline Author/Title & Study Design & $\begin{array}{l}\text { Sample Type } \\
\& \text { Size }\end{array}$ & $\begin{array}{l}\text { Data } \\
\text { Sources }\end{array}$ & Setting & $\begin{array}{l}\text { Research } \\
\text { Questions/ } \\
\text { Hypothesis }\end{array}$ & Instruments & Results/Comments \\
\hline $\begin{array}{l}\text { Reis et al. } \\
(2010)\end{array}$ & $\begin{array}{l}\text { Qualitative, } \\
\text { interpretive }\end{array}$ & $\begin{array}{l}\text { Purposive, parents } \\
\text { of NICU patients } \\
(n=10)\end{array}$ & $\begin{array}{l}\text { Semistructured } \\
\text { interviews }\end{array}$ & $\begin{array}{l}\text { Tertiary-level care } \\
69-\text { bed NICU in } \\
\text { Alberta, Canada }\end{array}$ & $\begin{array}{l}\text { Explore parental } \\
\text { perceptions of the } \\
\text { nurse's contribution } \\
\text { to the parents' NICU } \\
\text { experience \& their } \\
\text { satisfaction with the } \\
\text { care of the infants }\end{array}$ & NONE & $\begin{array}{l}\text { Perceptive engagement, } \\
\text { cautious guidance, and subtle } \\
\text { presence were seen as } \\
\text { antecedents in development } \\
\text { of their relationship with the } \\
\text { bedside nurse. Ideal nurses } \\
\text { seen as teacher, guardian, } \\
\text { and facilitator. Presence is } \\
\text { described as being available } \\
\& \text { accessible to parents to } \\
\text { support them, offering } \\
\text { constructive correction, and } \\
\text { providing parents with positive } \\
\text { affirmation. A model of } \\
\text { negotiated partnership is } \\
\text { provided. }\end{array}$ \\
\hline $\begin{array}{l}\text { Turner- } \\
\text { Stokes (2006) }\end{array}$ & Hermeneutic & $\begin{array}{l}\text { Convenience, } \\
\text { registered nurses } \\
(n=14)\end{array}$ & Individual interviews & $\begin{array}{l}\text { Acute care hospital } \\
\& \text { long-term care } \\
\text { facility in Melbourne, } \\
\text { Australia }\end{array}$ & $\begin{array}{l}\text { Understand the } \\
\text { hope-facilitation } \\
\text { strategies used } \\
\text { while caring for } \\
\text { patients }\end{array}$ & NONE & $\begin{array}{l}\text { Two emergent themes: } \\
\text { connecting with the inner } \\
\text { being \& journeying with them, } \\
\text { building trust over time are } \\
\text { aligned with presencing. Type } \\
\text { of facility and potentially length } \\
\text { of time together impacted the } \\
\text { depth of hope facilitation. }\end{array}$ \\
\hline
\end{tabular}

summary, inpatient research has focused evenly on nurse and patient perceptions of nursing presence. Studies for the most part utilized convenience or purposive samples and the majority of studies were conducted in the United States and Canada. The largest multi-center, quantitative survey was conducted in six European counties and investigated caring behaviors as its primary goal, but results had significant implications regarding the difference between nurse and patient perceptions of presence. The results of this systematic review indicate that inpatient research on this traditionally elusive concept has increased but is slow with only 15 studies being published in the 12 years since the last state of the science report. Few of the research studies (both inpatient and outpatient) specifically identified their theoretical foundations, thus additional subsequent literature searches were conducted to identify all applicable nursing models or metrics.

\section{Research Question 3}

Nursing presence models. As stated earlier, nursing presence has been cited as a major component in several nursing theories (Benner, 1984; Leininger, 1991; Parse, 1981; Paterson \& Zderad, 1976; Swanson, 1991; Watson, 1985). A theoretical foundation for nursing presence theory is found in Kim's (2000) nursing theory which outlines four different domains within nursing (client domain, nurse-client domain, domain of practice, and the environment domain). Nursing presence resides within the nurse-client domain. After conducting an extensive search, 10 additional models/ frameworks were identified and are described in Table 3. These models are best explained in terms of level of specificity.

The broadest, macro view is provided by the relational self-organization in workforce redevelopment model (Ray \& Turkel, 2012). Nursing ethical decision points for whether to provide caring and presencing behaviors are shown to have a direct relationship on organizational success. The closely related theory of the relational work of nurses provides details on organizational factors that may inhibit or facilitate relational work of nurses (DeFrino, 2009). This theory provides more insight to why nurses disappear from practice in environments where relational work is not fostered and has implications for design of nurse workloads. The hierarchy of healing presence (Godkin, 2001 and Godkin \& Godkin, 2004) and Halldorsdottir's theory of caring (Halldorsdottir, 2012) are models that provide linear explanations of how caring and presence are achieved. Presencing takes place in the Halldorsdottir biogenic and bioactive phases. These two models may offer a structure for measurement of depth of nurses'

interpersonal experience with patients. Two models concentrate primarily on nurse attributes or actions the client receives from the nurse. The
Mayo nursing care model (Harms, Eversman, Matt-Hensrud, Ruen, \& Schroeder, 2010) identifies seven principle caring roles of the nurse, while the paradigm for nursing interventions (which is specific to suffering and chronic sorrow) identifies components of nurse inputs (Melvin \& Heater, 2004). This model also describes the client trajectory and outcomes. At the most intricate level, a hybrid model of Orlando's deliberative nursing process and the Crick and Dodge model of social information processing, shows many direct linear communication processes within the nursepatient relationship (Sheldon \& Ellington, 2008). This model might serve as a good framework for direct observational studies between nurses and patients due to its intricacy of detail regarding patient cues, encoding of communication and response. Finally two models, transformative nursing presence (Iseminger, Levitt, \& Kirk, 2009) and the mid-range theory of nursing presence (McMahon \& Christopher, 2011) offer the most general and comprehensive views of nursing presence.

The transformative nursing presence model outlines forces that serve as barriers to nursing presence along with transcendent practices that facilitate nursing presence. The experiential components of nursing presence and the outcomes are also included at the patient, nurse, organization, and community levels. This theory provides key precursors required for nursing 
Table 3.

Key Theoretical Models/Frameworks of Nursing Presence

\begin{tabular}{|c|c|c|}
\hline Model/Framework & Theorist/Author(s) & Description \\
\hline $\begin{array}{l}\text { Halldorsdottir's } \\
\text { theory of caring } \\
\text { AND nurse's } \\
\text { compassionate } \\
\text { competence }\end{array}$ & $\begin{array}{l}\text { Bailey (2011) } \\
\text { Halldorsdottir (1991) } \\
\text { Halldorsdottir \& Karlsdottir (1996) } \\
\text { Halldorsdottir (2012) }\end{array}$ & $\begin{array}{l}\text { Caring to Uncaring Continuum - Five Basic Modes of Being with Another: Life-Giving - } \\
\text { biogenic, Life-Sustaining - bioactive, Life-Neutral - biopassive, Life-Restraining - biostatic, } \\
\text { Life-Destroying - biocidic. Nursing presence likely occurs during biogenic and bioactive } \\
\text { modes. Potential guide for employing nurse presence and/or measuring it. Compassionate } \\
\text { competence includes wisdom, clinical competence, communication/connection, } \\
\text { attentiveness, self-knowing/development and caring. }\end{array}$ \\
\hline $\begin{array}{l}\text { Hierarch of healing } \\
\text { presence }\end{array}$ & $\begin{array}{l}\text { Godkin (2001) } \\
\text { Godkin \& Godkin (2004) }\end{array}$ & $\begin{array}{l}\text { Nursing presence is described in a linear ascending fashion beginning with bedside presence } \\
\text { (uniqueness, \& connecting with the patient experience) extending to clinical presence } \\
\text { (sensing \& going beyond scientific data), then extending to healing presence (know what \& } \\
\text { when to act, being present). As nurse task maturity grows, the nurse presence capability is } \\
\text { optimized. Nursing presence indicators are outlined in the } 2004 \text { article. }\end{array}$ \\
\hline $\begin{array}{l}\text { Mayo nursing care } \\
\text { model }\end{array}$ & Harms et al. (2010) & $\begin{array}{l}\text { The nurse-patient \& family relationship is lived through seven principle caring roles: caring } \\
\text { healer, problem solver, navigator, teacher, pivotal communicator, vigilant guardian, and } \\
\text { transformational leaders. }\end{array}$ \\
\hline $\begin{array}{l}\text { Mid-range theory of } \\
\text { nursing presence }\end{array}$ & McMahon \& Christopher (2011) & $\begin{array}{l}\text { Very comprehensive model represents nurse characteristics, client characteristics, and } \\
\text { compatibility factors within the nurse-client dyad (relationship). Key components of nursing } \\
\text { presence and variables influencing its successful application are outlined. Nurse determines } \\
\text { level of intentionality, and select dose \& delivery mode of presence. Desired client outcomes } \\
\text { are listed. }\end{array}$ \\
\hline $\begin{array}{l}\text { Orlando's theory of } \\
\text { deliberative nursing } \\
\text { process and Crick \& } \\
\text { Dodge model of } \\
\text { social information } \\
\text { processing }\end{array}$ & Sheldon \& Ellington (2008) & $\begin{array}{l}\text { A hybrid model is proposed. The nurse encodes and interprets patient cues using thought } \\
\text { and feeling, producing arousal regulation, response access, and response decision. Nurse } \\
\text { performs activity that is deliberate and reciprocal based on additional data intake from } \\
\text { ongoing patient cues and responses. }\end{array}$ \\
\hline $\begin{array}{l}\text { Paradigm for nursing } \\
\text { interventions } \\
\text { Suffering and chronic } \\
\text { sorrow }\end{array}$ & Melvin \& Heater (2004) & $\begin{array}{l}\text { Through enacting of nursing presence, the client receives expert communication skills, } \\
\text { compassion, human touch, trust, and honesty. These inputs move the client to experience } \\
\text { self transcendence, autonomy, feeling of truly being heard, with decreases in isolation, } \\
\text { abandonment, and despair. Outcomes include the client finding meaning and peace. }\end{array}$ \\
\hline $\begin{array}{l}\text { Relational self- } \\
\text { organization in } \\
\text { workforce } \\
\text { redevelopment }\end{array}$ & Ray \& Turkel (2012) & $\begin{array}{l}\text { Nurse ethical decision points (to provide care in manner consistent with caring \& presencing) } \\
\text { have a direct impact (positively or negatively) on organizational success. }\end{array}$ \\
\hline $\begin{array}{l}\text { Theory of the } \\
\text { relational work of } \\
\text { nurses }\end{array}$ & DeFrino (2009) & $\begin{array}{l}\text { Derived from parent theory of relational work of women (Fletcher et al., 2000), this model } \\
\text { presents how nurses use relational work to preserve work, self-achieve, create team, and } \\
\text { mutually empower. Factors causing relational practices of nurses to disappear are presented } \\
\text { (likely important in the design of workload to facilitate improved relational practice and } \\
\text { retention in practice). }\end{array}$ \\
\hline $\begin{array}{l}\text { Transformative } \\
\text { nursing presence } \\
\text { model }\end{array}$ & Iseminger et al. (2009) & $\begin{array}{l}\text { Actual and perceived barriers to nursing presence identified. Transcendent practices are } \\
\text { employed that lead to enhanced nursing presence, and then lead to patient/family and nurse } \\
\text { outcomes/benefits. Transcendent practices include awareness, empathic appreciation, } \\
\text { appreciative abandonment, respectful listening, skilled communication, selective focusing, } \\
\text { availability, awe, openness, flexibility, supportive milieu, embrace another's situation, } \\
\text { alignment with organization. }\end{array}$ \\
\hline
\end{tabular}


presence capability but does not clearly outline what happens within the process. It therefore provides several domains for instrument development about nursing practices, but is less useful for training nursing students. The midrange theory of nursing presence, on the other hand, is better suited for nurse student education on the process of nursing presence.

The mid-range theory of nursing presence was postulated as a specific theoretical framework within the last two years (McMahon \& Christopher, 2011). The mid-range theory of nursing presence depicts the micro vision of the nurse-managed intervention. It provides key information regarding nurse capability requirements including knowledge and maturities (professional, moral, relational, and personal) which lead to the nurses' ability to recognize need when they are open to the patient. The use of presence is a deliberate intention which is delivered by a dose which is chosen by the nurse along with delivery mode. The patient's individual needs determine his or her openness to enter into presence. Desired patient outcomes are also outlined. This theory depicts the most comprehensive model, while portraying an understandable process for nursing students and entry level nurses to reflect upon during practice situations. Because of the comprehensive nature, it is a good overall template for metric development to measure student or nurse interactions with patients. In summary, many of these models could be effectively used as foundations for further instrument development, dependent on the desired level of specificity for measurement. Finally, the systematic review was continued to evaluate existence of already developed metrics.

Nursing presence metrics. To date, only a few initial attempts have been made at quantitative measurement of nursing presence. Only three metrics with overall purpose of measuring nursing presence were identified. Two measure nursing presence from the nurse perspective. The Measurement of Presence Scale (MOPS) was developed by Hines (1991) as part of dissertation work and further studied in subsequent dissertation (Foust, 1998). The MOPS is a 60 -item scale developed by systematic theory analysis, and content was validated from a panel of experts. It was initially tested with a sample of 324 nurses to measure nurse perception of nursing presence. Internal consistency reliability (Cronbach's alpha) was 0.9324 . Subscale alpha correlation coefficients were all greater than 0.60 . Factor analysis led to nine mutually exclusive subscales. Correlation between subscales and total MOPS were significant $(p=0.01)$, leading the researcher to assert that the tool was supported.
In 1998, Foust retested the instrument with a random sample of 210 registered nurses. A Measurement of Presence Visual Analog Scale (MOPVAS) was developed by Foust and tested along with the original tool (MOPS) as well as the Rosenberg Self-Esteem Scale (RSES). Presence (via original MOPS) and self-esteem levels were high with respective means of $231,(S D=16.52)$ and $34,(S D=4.46)$. The MOPVAS mean was $85,(S D=1.73)$. Reliability for MOPS (Cronbach's alpha) was 0.9106 , for the selfesteem scale, 0.8571; and for the MOPVAS, 0.8512 . Construct validity was supported with low correlations of MOPS and MOPVAS $(r=0.263$, $p=0.01)$ and MOPS and RSES $(r=0.329$, $p=0.01$ ). Factor analysis on second study data produced similar but not exactly the same subscale factors likely indicating the need for further instrument testing. While these studies showed support for the Measurement of Presence Scale, no other studies were located in which instrument development were tested. This is indicative of minimal instrument development in measuring nursing presence from the nurse perspective. Similar results were found in review of nursing presence instrument development which measured nursing presence from the patient's perspective.

The final tool identified by this review evaluated nursing presence from the patient's perspective and has been used by two researchers (Kostovich, 2002; Hansbrough, 2011), both of which were part of dissertations. Kostovich (2002) developed the Presence of Nursing Scale (PONS). This 25-item scale was tested on a sample of 330 acutely ill, medicalsurgical patients in four units of a mid-western hospital (Kostovich (2011). Content validity was established by four expert reviewers. In the initial study, construct validity was established by comparing the total instrument score with a single-item measure of patient satisfaction with a very high positive correlation ( $r p b=.801)$. Reliability (Cronbach's alpha) was 0.95 and testretest reliability was 0.729 . Exploratory factor analysis was not conducted; therefore, potential patterns of relationships between the tool subscales were not evaluated. This tool has been subsequently tested in the Veteran's Administration system in acute care and longterm care with a sample of 102 patients by the original developer (unpublished at present) and in a West Coast hospital (Hansbrough, 2011).

Hansbrough retested the PONS with a convenience sample of 75 hospitalized patients. Again the PONS was tested against a single-item measure of patient satisfaction. PONS was again reliable with Cronbach's alpha of 0.937 and correlation with a patient satisfaction measure was strong and statistically significant $(p>0.01)$. Again, no factor analysis was reported for this study.
In addition to instruments specific to nursing presence measurement, there are potentially other instruments in use that measure the patient's perspective of the nurse/patient interrelational experience. These tools could offer insight to the further development of the Presence of Nursing Scale, and/or if used in concert, serve to potentially demonstrate convergent construct validity. Additional instruments for consideration are found in Table 4.

\section{Limitations}

This review was conducted by a single researcher as part of the requirements for doctor of philosophy study in nursing. Time limitations prevented more in-depth analysis of all potential instruments designed to measure additional components of the nurse-patient interaction. Due to these limits, the review contains only tools that had immediate pertinence to nursing presence. Additionally, analysis of potential presence models or metrics from other disciplines was not undertaken.

\section{Recommendations}

This analysis found that there are similarities between presence in nursing and presence in other therapeutic professional relationships, however there is a large gap in the literature for interdisciplinary research or research designed to carve out the uniqueness of nursing presence. Nurse educators are uniquely situated to study similarities between nursing presence and teacher presence. More interprofessional concept development studies are needed to clarify similarities or differences. Non-nursing disciplines also need more in-depth attention to concept analysis and concept development endeavors to form the distinct components of their concepts of presence.

While inpatient research is likely crucial given the potential concern over imminent loss of nursing presence capability, the progress on this knowledge development has been slow. There is a great need for additional research that further identifies inpatient perception of nursing presence given the healthcare climate. Further studies are indicated that use measurement scales and instruments to determine if presence in nursing is being measured adequately across different patient populations. For existing instruments, it is essential that exploratory and confirmatory factor analysis be conducted to further develop and evaluate their ability to measure this phenomenon. New instruments need to be developed based on the improved definition and conceptual development of nursing presence over the last decade. Further qualitative studies need to be initiated to explore the nuance of presence in nontraditional healthcare settings, including telehealth environments. Nursing care environments might 
Table 4.

Instruments Relevant to Measurement of Nursing Presence

\begin{tabular}{lll}
\hline Instrument & Author & Description \\
\hline Caring Behaviors Inventory - 24 & $\begin{array}{l}\text { Wolf et al. (1994) } \\
\text { Papastavrou et al. } \\
(2010)\end{array}$ & $\begin{array}{l}\text { Revised from the original 43-item tool to 24 items. } \\
\text { Based on Watson's transpersonal caring theory. } \\
\text { Contains a sub-scale of "assurance of human }\end{array}$ \\
& $\begin{array}{l}\text { presence" and thus could be a potential construct } \\
\text { validity measure. }\end{array}$ \\
$\begin{array}{ll}\text { Caring nurse-patient interaction } \\
\text { scale (CNPI-short scale) }\end{array}$ & $\begin{array}{l}\text { Cosette et al. (2006) } \\
\text { Revised from an original 70-item questionnaire, } \\
\text { the tool contains 23 items reflecting four caring } \\
\text { domains: humanistic care, relational care, clinical } \\
\text { care, and comforting care. }\end{array}$
\end{tabular}

Nurse caring patient scale Della-Monica (2008)

Developed from a metasynthesis of patient descriptors within a "mid-range theory of Nurse Caring." Contains three attributes: 1) Presence, concern for the other; 2) Knowledgeable, competent care; and 3) Respect for the person.

Reliability and Validity Data

Internal consistency (Cronbach's alpha) $=0.94$ (nurses); 0.96 (patients).

All items relate to their theoretical domain alone (factor loading $>$ or $=$ $0.40)$. Alpha coefficients for the four domains $=0.63-0.74,0.90-0.92$, $0.80-0.94, \& 0.61-0.76$ respectively.

Factor analysis resulted in parsimonious three factor solution that accounted for $50.49 \%$ of the total variance. The final NCPS contained 23 items with an alpha of 0.91 . The presence item contains 11 items with an alpha of 0.89 .

Patient evaluation of emotional Williams et al. (2011)

Tool to evaluate quality of interpersonal interactions of staff that had been experienced during hospitalization. Originally containing 3 subscales of Level of Security, Level of Knowing, and Level of Personal Knowing.

Parcells \& Locsin (2011) Expresses five core assumptions of the theory with 5 items each. This is a modification from the original 30-item tool (Locsin, 1999). This revision was done by having 13 experts rate item validity. Several items are representative of nursing presence attributes or conditions.

Watson caritas patient score Watson, Brew, \& D'Alfonso (2010)
Contains five critical caring questions, with a 7-point Likert scale to assess frequency of authentic human caring practices. The items are derived from the 10 Caritas Processes $^{\mathrm{TM}}$ of Watson's human caring theory. The scale has different versions and has been translated into Italian, Hebrew, and Arabic.
Confirmatory factor analysis substantiated the four sub-scales. Cronbach's alpha coefficients ranged from $0.73-0.86$, however, the subscale for Level of Connection, was lower at 0.59 . This may be due to its being a new sub-scale.

Item validity rating range from .38 1.00. Items .70 and below were deleted and items rated $.70-.95$ were modified based on expert recommendations.

Is currently being evaluated in extensive multi-site clinical research in systems who have implemented the human caring model. benefit from institutional-based studies to evaluate how time management of presence is accomplished. These same environments need to be studied to determine best practices to promote healthy work environments that support the ability and time to demonstrate nursing presence.

As with all concepts, historical context is likely to have an impact or change understandings and use of concepts. With the emergence of technological advances, Finfgeld-Connett (2006) urged researchers interested in studying nursing presence to establish ways to preserve nursing presence when deploying telehealth technology. Sandelowski (2002) warned about the potential implications that technology will have on our ability to enact a true nursing presence in the future. In response to contextual change for nursing presence, few authors have conducted studies in relation to this new virtual nursing presence (Finfgeld-Connett, 2005; Savenstedt, Zingmark, \& Sandman, 2004; SchlachtaFairchild, Varghese, Deickman, \& Castelli, 2010). The resulting derived concept of telepresence was defined as "the subjective experience of being together with a person in one place when one is geographically situated in another" (Savenstedt et al., 2004, p. 1047). To date, there have been no instruments tested to evaluate patient perception of nurse virtual presence and whether it differs from physical nursing presence. Further review, analysis, and refinement are indicated.

\section{References}

Andrus, V. (2013). Caring presence: The key to improving the patient experience. Advance for Nurses, 15(9), 14-15.

Bailey, D. (2011). Framing client care using Halldorsdottir's theory of caring and uncaring Behaviors within nursing and healthcare. International Journal for Human Caring, 15(4), 54-66.

Baldoni, J. (2010). 12 steps to power presence: How to assert your authority to lead. New York, NY: American Management Association.

Bangert, A. (2008). The influence of social presence and teaching presence on the quality of online critical inquiry. Journal of Computing in Higher Education, 20(1), 34-61.

Benner, P. (1984). From novice to expert: Excellence and power in clinical practice. Menlo Park, CA: Addison-Wesley. 
Benner, P. (2004). Relational ethics of comfort, touch, and solace-Endangered arts? American Journal of Critical Care, 13, 346-349.

Brown, L. (1986). The experience of care: Patient perspectives. Topics in Clinical Nursing, 8(2), 56-62.

Buber, M. (1970). I and thou (W. Kaufmann, Trans.). New York, NY: Simon \& Schuster (original work published in 1937).

Busch, M., Visser, A., Eybrechts, M., Komen, R., Oen, I., Olff, M., Dokter, J., \& Boxma, H. (2012). The implementation and evaluation of therapeutic touch in burn patients: An instructive experience of conducting a scientific study within a non-academic nursing setting. Patient Education and Counseling, 89, 439-446.

Cantrell, M., \& Matula, C. (2009). The meaning of comfort for pediatric patients with cancer. Oncology Nursing Forum, 36, E303-E309.

Cohen, M., Hausner, J., \& Johnson, M. (1994). Knowledge and presence: Accountability as described by nurses and surgical patients. Journal of Professional Nursing, 10, 177-185.

Cooper, H. (1998). Synthesizing research. (3rd ed.), Thousand Oaks, CA: Sage.

Cossette, S., Cote, J., Pepin, J., Ricard, N., \& D'Aoust, L. (2006). A dimensional structure of nurse-patient interactions from a caring perspective: Refinement of the Caring NursePatient Interaction Scale (CNPI-Short Scale). Journal of Advanced Nursing, 55, 198-214.

Crane-Okada, R. (2012). The concept of presence in group psychotherapy: An operational definition. Perspectives in Psychiatric Care, 48, 156-164.

Crick, N., \& Dodge, K. (1994). A review and reformulation of social-information processing mechanisms in childrens' social adjustment, Psychological Bulletin, 1(15), 74-101.

Davis, L. (2005). A phenomenological study of patient expectations concerning nursing care. Holistic Nursing Practice, 19, 126-133.

DeFrino, D. (2009). A theory of the relational work of nurses. Research and Theory for Nursing Practice, 23, 294-311.

Della-Monica, N. (2008). Development and psychometric evaluation of the Nurse Caring Patient Scale. (Order No. 3310341, Boston College). ProQuest Dissertations and Theses. Retrieved from http://search.proquest.com/ docview/89122903?accoutid $=28833$. (89122903).

Department of Health and Human Services. (2012). Federal register part II, 77(170), 1-494. Retrieved from www.gpo.gov/fdsys/ pkg/FR-2012-08-31/pdf/2012-19079.pdf

Doona, M., Chase, S., \& Haggerty, L. (1999). Nursing presence: As real as a Milky Way bar. Journal of Holistic Nursing, 17(1), 54-70.
Doona, M., Haggerty, L., \& Chase, S. (1997). Nursing presence: An existential exploration of the concept. Scholarly Inquiry for Nursing Practice, 11(1), 3-16.

Dossey, B. (2000). Florence Nightingale: Mystic, visionary, healer. Philadelphia, PA: Lippincott Williams \& Wilkins.

Duis-Nittsche, E. (2002). A study of nursing presence. (Order No. 3066651, The University of Texas Graduate School of Biomedical Sciences at Galveston). ProQuest Dissertations and Theses. Retrieved from http://search.proquest.com/docview/2764023 78?accountid=28833. (276402378).

Dunn, R., Callahan, J., Swift, J., \& Ivanovic, M. (2013). Effects of pre-session centering for therapists on session presence and effectiveness, Psychotherapy Research, 23(1), 78-85.

Easter, A. (2000). Construct analysis of four modes of being present. Journal of Holistic Nursing, 18, 362-377.

Edvardsson, D., Sandman, P., \& Rasmussen, B. (2011). Forecasting the ward climate: A study from a dementia care unit. Journal of Clinical Nursing, 21, 1136-1144.

Fairhurst, G., \& Cooren, F. (2009). Leadership as the hybrid production of presence(s). Leadership, 54, 469-490.

Feldstein, P. J. (2005). Health care economics (6th ed.). Victoria, Australia: Thomson Delmar Learning.

Fengfeng, K. (2010). Examining online teaching, cognitive, and social presence for adult students. Computers \& Education, 55, 808-820.

Ferlic, A. (1968). Existential approach in nursing. Nursing Outlook, 16, 30-33.

Finfgeld-Connett, D. (2005). Telephone social support or nursing presence? Qualitative Health Research, 15(1), 19-29.

Finfgeld-Connett, D. (2006). Meta-synthesis of presence in nursing. Journal of Advanced Nursing, 55, 708-714.

Finfgeld-Connett, D. (2008). Qualitative comparison and synthesis of nursing presence and caring. International Journal of Nursing Terminologies and Classifications, 19, 111-119.

Finfgeld-Connett, D. (2008). Qualitative convergence of three nursing concepts: Art of nursing, presence and caring. Journal of Advanced Nursing, 63, 527-534.

Fletcher, J., Jordan, J., \& Miller, J. (2000). Women and the workplace: Applications of a psychodynamic theory. American Journal of Psychoanalysis, 60, 243-261.
Foust, C. (1998). Refinement of the measurement of presence scale. (Order No. 9916239, Texas Woman's University). ProQuest Dissertations and Theses. Retrieved from http://search.proquest.com/ docview/304488057?accountid=28833. (304488057).

Fraelich, C. (1989). A phenomenological investigation of the psychotherapist's experience of presence. Dissertation Abstracts International, 50(4-B). (UMI No. 8904935).

Fredriksson, L. (1999). Modes of relating in a caring conversation: A research synthesis on presence, touch and listening. Journal of Advanced Nursing, 30, 1167-1176.

Fuller, J. G. (1991). A conceptualization of presence as a nursing phenomenon. (Order No. 9200949, University of Utah). ProQuest Dissertations and Theses. Retrieved from http://search.proquest.com/docview/3039546 13? accountid=28833. (303954613)

Garrison, D., Cleveland-Ines, M., Fung, T. (2010). Exploring causal relationships among teaching, cognitive and social presence: Student perceptions of the community of inquiry framework. Internet and Higher Education, 13, 31-36.

Geller, S. M. (2001). Therapists' presence: The development of a model and a measure. (Order No. NQ66348, York University (Canada). ProQuest Dissertations and Theses. Retrieved from http://search. proquest.com/docview/304730351? accountid=28833. (304730351).

Geller, S., \& Greenberg, L. (2002). Therapeutic presence: Therapists' experience of presence in the psychotherapy encounter. PersonCentered and Experiential Psychotherapies, 1(1-2), 71-86.

Geller, S., Greenberg, L., \& Watson, J. (2010). Therapist and client perceptions of therapeutic presence: The development of a measure. Psychotherapy Research, 20, 599-610.

Giddens, J., \& Brady, D. (2007). Rescuing nursing education from content saturation: The case for a concept-based curriculum. Journal of Nursing Education, 46(2), 65-69.

Godkin, J. (2001). Healing presence. Journal of Holistic Nursing, 19(1), 5-26.

Godkin, J., \& Godkin, L. (2004). Caring behaviors among nurses: Fostering a conversation of gestures. Health Care Management Review, 29, 258-267.

Granick, J. L. (2011). Transpersonal aspects of therapists' presence: What do clients experience? (Order No. 3495276, Institute of Transpersonal Psychology). ProQuest Dissertations and Theses. Retrieved from http://search.proquest.com/docview/9236178 89? accountid=28833. (923617889). 
Hain, A., Logan, J., Cragg, B., \& Van den Berg, R. (2007). Presence: Coming to know the whole. How expert nurses practice in a critical care unit. Dynamics, 18(2), 19-20.

Halldorsdottir, S. (1991). Five basic modes of being with another. In D.A. Gaut \& M.M. Leininger (Eds.), Caring: The compassionate healer (pp. 37-49), New York, NY: National League for Nursing Press.

Halldorsdottir, S. (2012). Nursing as compassionate competence: A theory on professional nursing care based on the patient's perspective. International Journal for Human Caring, 16(2), 7-19.

Halldorsdottir, S., \& Karlsdottir, S. (1996). Empowerment or discouragement: Women's experience of caring and uncaring encounters during childbirth. Health Care for Women International, 17, 361-379.

Halpern, B., \& Lubar, K. (2004). Leadership presence: Dramatic techniques to reach out, motivate and inspire. New York, NY: Gotham Books.

Hansbrough, W. (2011). Examining nursing presence in the acute care setting as an indicator of patient satisfaction with nursing care. (Order No. 3475617, University of San Diego). ProQuest Dissertations and Theses. Retrieved from http://search.proquest.com/ docview/892725770?accountid=28833. (892725770)

Hanson, M. (2004). Using data from critical care nurses to validate Swanson's phenomenological derived middle-ranged caring theory. Journal of Theory Construction \& Testing, 8(1), 21-25.

Harms, H., Eversman, C., Matt-Hensrud, N., Ruen, N, \& Schroeder, B. (2010). Actualizing the Mayo Nursing Care Model, International Journal for Human Caring, 14(3), 81.

Heidegger, M. (1962). Being and time (J. Macquarrie \& E. Robinson, Trans.). New York, NY: Harper \& Row (original work published in 1927).

Hessel, J. (2009). Presence in nursing practice: A concept analysis. Holistic Nursing Practice, 23, 276-281.

Hines, D. R. (1991). The development of the measurement of presence scale. (Order No. 9203067, Texas Woman's University). ProQuest Dissertations and Theses. Retrieved from http://search.proquest.com/ docview/303970144? ?accountid=28833. (303970144)

Hines, D. (1992). Presence: Discovering the artistry in relating. Journal of Holistic Nursing, 10, 294-305.

Iseminger, K., Levitt, F., \& Kirk, L. (2009). Healing during existential moments: The "art" of nursing presence. Nursing Clinics of North America, 44, 447-459.
Jackson, C. (2004). Healing ourselves, healing others. Holistic Nursing Practice, 18, 127-141.

$\mathrm{Kim}, \mathrm{H}$. (2000). The nature of theoretical thinking in nursing (2nd ed.). New York, NY: Springer.

Kirkevold, M. (1997). Integrative nursing research-an important strategy to further the development of nursing science and nursing practice. Journal of Advanced Nursing, 25, 977-984

Koerner, J. (2007). Healing presence: The essence of nursing. New York, NY: Springer.

Kornelson, L. (2006). Teaching with presence. New Directions for Adult and Continuing Education, 111, 73-82.

Kostovich, C. T. (2002). Development of a scale to measure nursing presence. (Order No. 3039289, Loyola University of Chicago). ProQuest Dissertations and Theses. Retrieved from http://search.proquest.com/ docview/305586866 ?accountid=28833. (305586866)

Kostovich, C. (2002). Development of a scale to measure nursing presence. Loyola University, Chicago: IL, unpublished doctoral dissertation.

Kostovich, C. (2011). Development and psychometric assessment of the Presence of Nursing Scale. Nursing Science Quarterly, 25, 167-175.

Leininger, M. (1991). Culture care diversity and universality: A theory of nursing. New York, NY: National League for Nursing Press.

Locsin, R. (1999). Development of an instrument to measure technological caring in nursing. Nursing \& Health Sciences, 1(1), 27-34.

MacKinnon, K., Mclntyre, M., \& Quance, M. (2005). The meaning of the nurse's presence during childbirth. Journal of Obstetric, Gynecologic, and Neonatal Nursing, 34(1), 28-36.

Malinski, V. (2002). Developing a nursing perspective on spirituality and healing. Nursing Science Quarterly, 15, 281-287.

Marcel, G. (1951). The mystery of being (2 vols.). Chicago, IL: Henry Regnery.

McCollum, E., \& Gehart, D. (2010). Using mindfulness meditation to teach beginning therapists therapeutic presence: A qualitative study. Journal of Marital \& Family Therapy, 3 , 347-360.

McEwen, M. (2007). Philosophy, science, and nursing. In theoretical basis for nursing (2nd ed.). Philadelphia, PA: Lippincott Williams \& Wilkins.

McKivergin, M., \& Daubenmire, M. (1994). The healing process of presence. Journal of Holistic Nursing, 12(1), 65-81.

McMahon, M., \& Christopher, K. (2011). Toward a mid-range theory of nursing presence. Nursing Forum, 46(2), 71-82.
Meijer, P., Korthagen, F., \& Vasalos, A. (2009). Supporting presence in teacher education: The connection between the person and professional aspects of teaching. Teaching and Teacher Education, 25, 297-308.

Melnechenko, K. (2003). To make a difference: Nursing presence. Nursing Forum, 38(2), 18-24.

Melvin, C., \& Heater, B. (2004). Suffering and chronic sorrow: Characteristics and a paradigm for nursing interventions. International Journal for Human Caring, 8(2), 41-47.

Metcalf, S., \& Putnam, A. (2013). The net generation of nursing: Keeping empathetic communication alive. Creative Nursing, 19(1), 21-25.

Minicucci, D. (1998). A review and synthesis of the literature: The use of presence in the nursing care of families. Journal of the New York State Nurses Association, 29(3/4), 9-15.

Mohnkern, S. M. (1992). Presence in nursing: Its antecedents, defining attributes and consequences. (Order No. 9225674, The University of Texas at Austin). ProQuest Dissertations and Theses. Retrieved from http://search.proquest.com/docview/3040376 09? accountid=28833. (304037609)

Morse, J. (2004). Constructing qualitatively derived theory: Concept construction and concept typologies. Qualitative Health Research, 14, 1387-1395.

Newman, M. (1986). Health as expanding consciousness. St. Louis, MO: Mosby.

Newman, M. (2008). Transforming presence: The difference that nursing makes. Philadelphia, PA: F.A. Davis.

Orlando, I. (1972). The discipline and teaching of nursing process (An evaluative study). New York, NY: G.P. Putnam's Sons.

Osterman, P., \& Schwartz-Barcott, D. (1996). Presence: Four ways of being there. Nursing Forum, 2, 23-30.

Osterman, P., Schwartz-Barcott, D., \& Asselin, M. (2010). An exploratory study of nurses' presence in daily care on an oncology unit. Nursing Forum, 45, 197-205.

Papastavrou, E., Efstathiou, G., Tsangari, H., Suhonen, R., Leino-Kilpi, H., Patiraki, E., Karlou, C., Balogh, Z., Palese, A., Tomietto, M., Jarosova, D., \& Merkouris, A. (2011). A crosscultural study of the concept of caring through behaviours: Patients' and nurses' perspectives in six different EU countries. Journal of Advanced Nursing, 68, 1026-1037.

Parcells, D., \& Locsin, R. (2011). Development and psychometric testing of the Technological Competency as Caring in Nursing Instrument. International Journal for Human Caring, 15(4), 8-13. 
Parse, R. (1981). Man-living-health: A theory of nursing. New York, NY: John Wiley.

Paterson, J., \& Zderad, L. (1976). Humanistic nursing. New York, NY: John Wiley.

Pederson, C. (1993). Presence as a nursing intervention with hospitalized children. Maternal-Child Nursing Journal, 21(3), 75-81.

Peplau, H. (1952). Interpersonal Relations in Nursing. New York, NY: G.P. Putnam's Sons.

Pettigrew, J. M. (1988). A phenomenological study of the nurse's presence with persons experiencing suffering. (Order No. 8821422, Texas Woman's University). ProQuest Dissertations and Theses. Retrieved from http://search.proquest.com/docview/3036402 87 ? accountid=28833. $(303640287)$

Pettigrew, J. (1990). Intensive nursing care. The ministry of presence. Critical Care Nursing Clinics of North America, 2, 503-508.

Ray, M., \& Turkel, M. (2012). A transtheoretical evolution of caring science within complex systems. International Journal for Human Caring, 16(2), 28-33.

Reis, M., Rempel, G., Scott, S., Brady-Fryer, B., \& Aerde, J. (2010). Developing nurse/patient relationships in the NICU through negotiated partnership. Journal of Obstetric, Gynecologic, \& Neonatal Nursing, 39, 675-683.

Robbins, M. (1998). Therapeutic presence in holistic psychotherapy. In Therapeutic presence: bringing expression and form (pp. 153-181). London, United Kingdom: Jessica Kingsley.

Rodgers, C., \& Raider-Roth, M. (2006). Presence in teaching. Teachers and teaching: Theory and practice, 12, 265-287.

Rogers, M. (1970). An introduction to the theoretical basis of nursing. Philadelphia, PA: F.A. Davis.

Rosengren, K., Athlin, E., \& Segesten, K. (2007). Presence and availability: Staff conceptions of nursing leadership on an intensive care unit. Journal of Nursing Management, 15, 522-529.

Rutherford, M. (2012). Nursing is the room rate. Nursing Economics, 30, 193-200.

Sandelowski, M. (2002). Visible humans, vanishing bodies, and virtual nursing: Complications of life, presence, place and identity. Advances in Nursing Science, 24(3), 58-70.

Savenstedt, S., Zingmark, K., \& Sandman, P. (2004). Being present in a distant room: Aspects of teleconsultations with older people in a nursing home. Qualitative Health Research, 14, 1046-1057.

Schlachta-Fairchild, L, Varghese, S., Deickman, A., \& Castelli, D. (2010). Telehealth and telenursing are live: APN policy and practice implications. Journal for Nurse Practitioners, 6, 98-106.
Schmidt, B., \& MacWilliams, B. (2011).

Admission criteria for undergraduate nursing programs. A systematic review. Nurse Educator, 36, 171-174.

Scouller, J. (2011). The three levels of leadership: How to develop your leadership presence. Gloucestershire, United Kingdom: Management Books 2000, Ltd.

Senge, P., Scharmer, C., Jaworski, J., \& Flower, B. (2004). Presence: An exploration of profound change in people, Organizations and society. New York, NY: Doubleday.

Sharda, R., Romano, N., Lucca, J., Weiser, M., Scheets, G., Chung, J., \& Sleezer, C. (2004). Foundation for the study of computersupported collaborative learning requiring immersive presence. Journal of Management Information Systems, 20(4), 31-63.

Shea, P., \& Bidjerano, T. (2009). Community of inquiry as a theoretical framework to foster "epistemic engagement" and "cognitive presence" in online education. Computers \& Education, 52, 543-553.

Shea, P., \& Bidjerano, T. (2010). Learning presence: Towards a theory of self-efficacy, self-regulation, and the development of a communities of inquiry in online and blended learning environments, Computers \& Education, 55, 1721-1731.

Shea, P. \& Vickers, J. (2010). Online instructional effort measured through the lens of teaching presence in the community of inquiry framework: A re-examination of measures and approach, International Review of Research in Open and Distance Learning, 11, 127-154.

Sheldon, L., \& Ellington, L. (2008). Application of a model of social information processing to nursing theory: How nurses respond to patients, Journal of Advanced Nursing, 64, 388-398.

Skott, C. (2001). Caring narratives and the strategy of presence: Narrative communication in nursing practice and research. Nursing Science Quarterly, 14, 249-254.

Smith, T. (2001). The concept of nursing presence: State of the science. Scholarly Inquiry for Nursing Practice, 15, 299-322.

Snyder, M., Brandt, C., \& Tseng, Y. (2000). Use of presence in the critical care unit. AACN Clinical Issues, 11(1), 27-33.

Stanley, K. (2002). The healing power of presence: Respite from the fear of abandonment. Oncology Nursing Forum, 29, 935-940.

Su, A., \& Wilkins, M. (2013). Own the room: Discover your signature voice to master your leadership presence. Boston, MA: Harvard Business School Publishing.
Swanson, K. (1991). Empirical development of a middle-range theory of caring. Nursing Research, 40, 161-166.

Tannen, T., \& Daniels, M. (2010). Counsellor presence: Bridging the gap between wisdom and new knowledge. British Journal of Guidance \& Counselling, 38(1), 1-15.

Tavernier, S. (2006). An evidence-based conceptual analysis of presence. Holistic Nursing Practice, 20, 152-156.

Travelbee, J. (1966). Interpersonal aspects of nursing. Philadelphia, PA: F. A. Davis.

Turner, d. S., \& Stokes, L. (2006). Hope promoting strategies of registered nurses. Journal of Advanced Nursing, 56, 363-372.

Vaillot, M. C. (1962). Commitment to nursing: A philosophic investigation. Philadelphia, PA: J. B. Lippincott.

Vaillot, M. C. (1966). Existentialism: A philosophy of commitment. American Journal of Nursing, 66, 500-505.

Watson, J. (1985). Nursing: Human science and human care. Norwalk, CT: Appleton Century.

Watson, J., Brewer, B. B., \& D'Alfonso, J. (2010). Watson Caritas Patient Survey (WCPS)(C) Boulder, CO: Watson Caring Science Institute.

Whittemore, R. (2005). Combining evidence in nursing research: Methods and implications, Nursing Research, 54(1), 56-62.

Williams, A., Pienaar, C., Toye, C., Joske, D., \& Lester, L. (2011). Further psychometric testing of an instrument to measure emotional care in hospital. Journal of Clinical Nursing, 20, 3472-3482.

Wolf, Z., Giardino, E., Osborne, P. \& Ambrose, M. (1994). Dimensions of nurse caring. Image, 26, 107-111.

Zyblock, D. (2010). Nursing presence in contemporary nursing practice. Nursing Forum, 45, 120-124.

\section{Author Note}

Rebecca L. Turpin, Assistant Professor, Tennessee Technological University, WhitsonHester School of Nursing, Cookeville, Tennessee.

Correspondence regarding this article should be addressed to Rebecca L. Turpin, $\mathrm{PhD}(\mathrm{c})$, MSN, RN, Assistant Professor, Tennessee Technological University, P.O. Box 5001, Cookeville, TN 38505 USA. Electronic mail may be sent via Internet to rturpin@tntech.edu 
Copyright of International Journal for Human Caring is the property of International Association for Human Caring and its content may not be copied or emailed to multiple sites or posted to a listserv without the copyright holder's express written permission. However, users may print, download, or email articles for individual use. 